\title{
ANALISIS NERACA AIR DAS SEMBUNG, KABUPATEN SLEMAN, DIY (Ketersediaan Air, Kebutuhan Air, Kekritisan Air)
}

\author{
${ }^{1}$ Afid Nurkholis, ${ }^{1}$ Yuli Widyaningsih, ${ }^{1}$ Ayu Dyah Rahma, ${ }^{1}$ Amalya Suci, ${ }^{1}$ Ardian Abdillah, ${ }^{1}$ Gina Aprila \\ Wangge, ${ }^{1}$ Arum Sari Widiastuti, ${ }^{1}$ Deka Ayu Maretya \\ ${ }^{1}$ Departemen Geografi Lingkungan, Fakultas Geografi, Universitas Gadjah Mada \\ email author: afidnurkholis@ gmail.com
}

\begin{abstract}
Abstrak
Data ketersediaan dan kebutuhan air merupakan dasar perhitungan potensi sumberdaya air. Satuan analisis penelitian ini menggunakan bentuklahan karena berpengaruh terhadap karakteristik dan pola pergerakan air serta hujan yang turun di suatu wilayah. Analisis sumberdaya air dapat digunakan untuk mengetahui kondisi sumberdaya air yang ada di suatu tempat, khususnya DAS Sembung yang meliputi ketersediaan meteorologis, ketersediaan airtanah dan air permukaan, serta kebutuhan air (domestik, irigasi, peternakan, dan industri). Hasil penelitian menunjukkan bahwa ketersediaan air meteorologis pada DAS Sembung akan mengalami surplus pada saat musim penghujan dan akan mengalami defisit pada saat musim kemarau. Kebutuhan air domestik pada DAS Sembung yang paling besar adalah pada bentuklahan lereng kaki sebesar $312.977 \mathrm{~m}^{3} /$ tahun. Kebutuhan air irigasi yang paling besar dimiliki oleh bentuklahan lereng kaki yaitu sebesar $5.563 .237 \mathrm{~m}^{3} /$ tahun. Kebutuhan air peternakan yang paling besar berada pada bentuklahan lereng kaki yaitu sebesar $14.250 \mathrm{~m}^{3} /$ tahun. Kebutuhan air perikanan yang paling besar berada pada bentuklahan lereng kaki sebesar $125.070 \mathrm{~m}^{3} /$ tahun. Kebutuhan air industri terbesar berada pada bentuklahan dataran kaki yaitu sebesar 103.824 $\mathrm{m}^{3} /$ tahun. Tingkat kekritisan air pada bentuklahan lereng kaki, dataran kaki, dan teras sungai pada DAS Sembung tergolong tidak kritis. Hal ini disebabkan karena potensi ketersediaan air yang banyak meliputi airtanah, air permukaan, dan mata air
\end{abstract}

kata kunci: neraca air, ketersediaan air, kebutuhan air, kekritisan air, DAS Sembung, sumberdaya air

\section{$\underline{\text { Sitasi model APA }}$}

Nurkholis, A., Widyaningsih, Y., Rahma, A. D., Suci, A., Abdillah, A., Wangge, G. A., Widiastuti, A. S., Maretya, D. A. (2016, March 30). Analisis Neraca Air DAS Sembung, Kabupaten Sleman, DIY (Ketersediaan Air, Kebutuhan Air, Kekritisan Air). http://doi.org/10.17605/OSF.IO/YMHKG 


\section{PENDAHULUAN}

Analisis evaluasi sumberdaya air dapat digunakan untuk mengetahui kondisi sumberdaya air yang ada di suatu tempat, khususnya DAS Sembung yang meliputi ketersediaan meteorologis, kekeringan meteorologis, ketersediaan airtanah, kebutuhan air (domestik, irigasi, peternakan, dan industri), kerentanan DAS, dan ketersediaan air permukaan. Selain itu, analisis sumberdaya air digunakan untuk mengetahui kualitas dan kuantitas air dalam DAS serta untuk mengetahui keterkaitan antara masing-masing faktor lahan dan air yang mempengaruhi kondisi air di DAS.

Ketersediaan air merupakan volume air yang terdapat dalam siklus hidrologi di suatu wilayah, yang merupakan gabungan dari air hujan, air permukaan, dan airtanah. Air hujan yang jatuh ke permukaan bumi akan mengalami proses evapotranspirasi, sebagian akan masuk ke dalam tanah, dan sisanya akan mengalir di permukaan bumi sebagai aliran permukaan menuju lokasi yang lebih rendah (Sosrodarsono dan Takeda, 2002). Aliran permukaan yang berkumpul akan membentuk aliran sungai, kemudian secara spasial dapat dibatasi sebagai Daerah Aliran Sungai (DAS). Ketersediaan air di suatu DAS merupakan hasil dari keseluruhan perhitungan ketersediaan air mulai dari meteorologis, air permukaan, dan airtanah. Perhitungan mengenai ketersediaan air penting untuk mengetahui potensi sumberdaya air di suatu wilayah (Asdak, 2007).

Data ketersediaan dan kebutuhan air merupakan dasar perhitungan potensi sumberdaya air. Sebagai satuan analisisnya penggunaan air menggunakan bentuklahan karena berpengaruh terhadap karakteristik dan pola pergerakan air serta hujan yang turun di suatu wilayah. Menurut Seyhan (1990) DAS yang terdiri dari tiga zona yaitu hulu, tengah, dan hilir masing-masing memiliki perbedaan potensi sumberdaya dan memiliki perbedaan dalam analisis. Perubahan lahan dan air sebagai sumberdaya dipengaruhi oleh aktivitas di bagian hulu tengah, dan hilir. Kelestarian sumberdaya lahan dan air harus dijaga dan dikelola dengan baik dan benar agar produktivitasnya optimal. Oleh karena itu, analisis sumberdaya air merupakan suatu hal yang penting.

\section{WILAYAH KAJIAN}

DAS Sembung merupakan bagian dari DAS Opak. DAS Sembung dibagi menjadi tiga zonasi yaitu hulu, tengah, dan hilir. Penutup lahan yang dominan di DAS Sembung yaitu sebagai pertanian, perkebunan, dan permukiman. Klasifikasi lereng di DAS Sembung berupa lereng yag datar dan landai. Formasi batuan yang terdapat pada DAS Sembung berupa Qmi/ Qvu3 yaitu Endapan Volkanik Merapi Muda yang terdiri dari tuff, abu, breksi, aglomerat, dan leleran lava tak terpisahkan. Formasi ini berhulu pada Gunungapi Merapi dan menyusun sebagian besar lereng 
Gunung Merapi. Formasi berumur kuarter dan masih terus mengalami proses erupsi. Material yang tersusun merupakan hasil dari akumulasi erupsi Gunung Merapi.

\section{METODE PENELITIAN}

\subsection{Hujan Wilayah}

Hujan wilayah menggambarkan rata-rata curah hujan yang terjadi pada suatu tempat berdasarkan karakteristik masing-masing wilayah. Penentuan curah hujan wilayah yang dilakukan dengan metode isohyet (Gambar 3.1). Data yang digunakan adalah data curah hujan bulanan (mm/bulan) dan luas wilayah DAS.

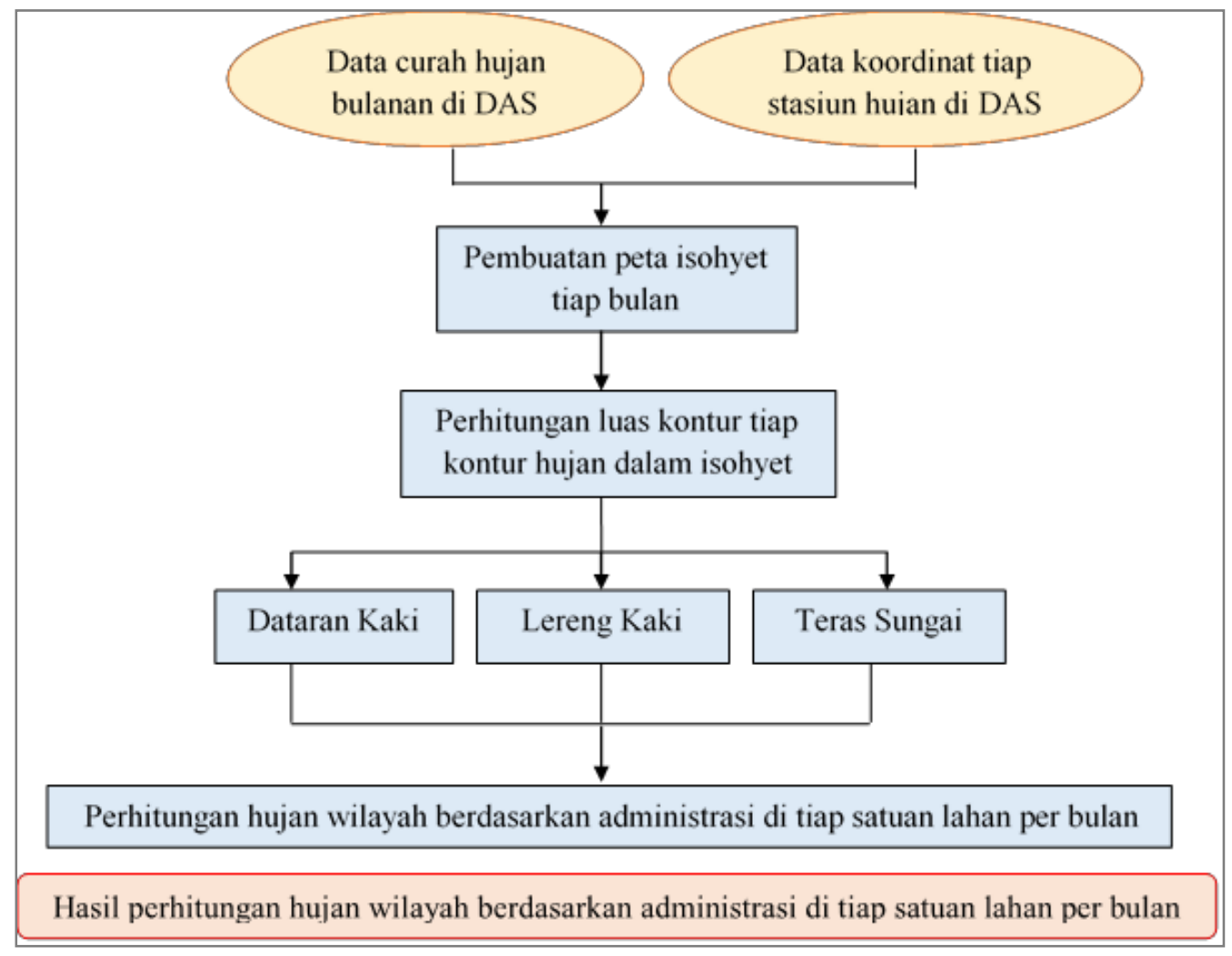

Gambar 3.1. Diagram Alir Perhitungan Hujan Wilayah

\subsection{Potensi Airtanah}

Potensi airtanah menggambarkan kuantitas dan kualitas airtanah yang terkandung dalam suatu akuifer. Potensi airtanah pada suatu akuifer tergantung pada porositas dan kemampuan tanah untuk meloloskan dan meneruskan air. Analisis potensi airtanah dilakukan dengan membuat peta arah aliran (flownet), perhitungan debit dinamis airtanah, dan perhitungan hasil aman (Gambar $3.2)$. 


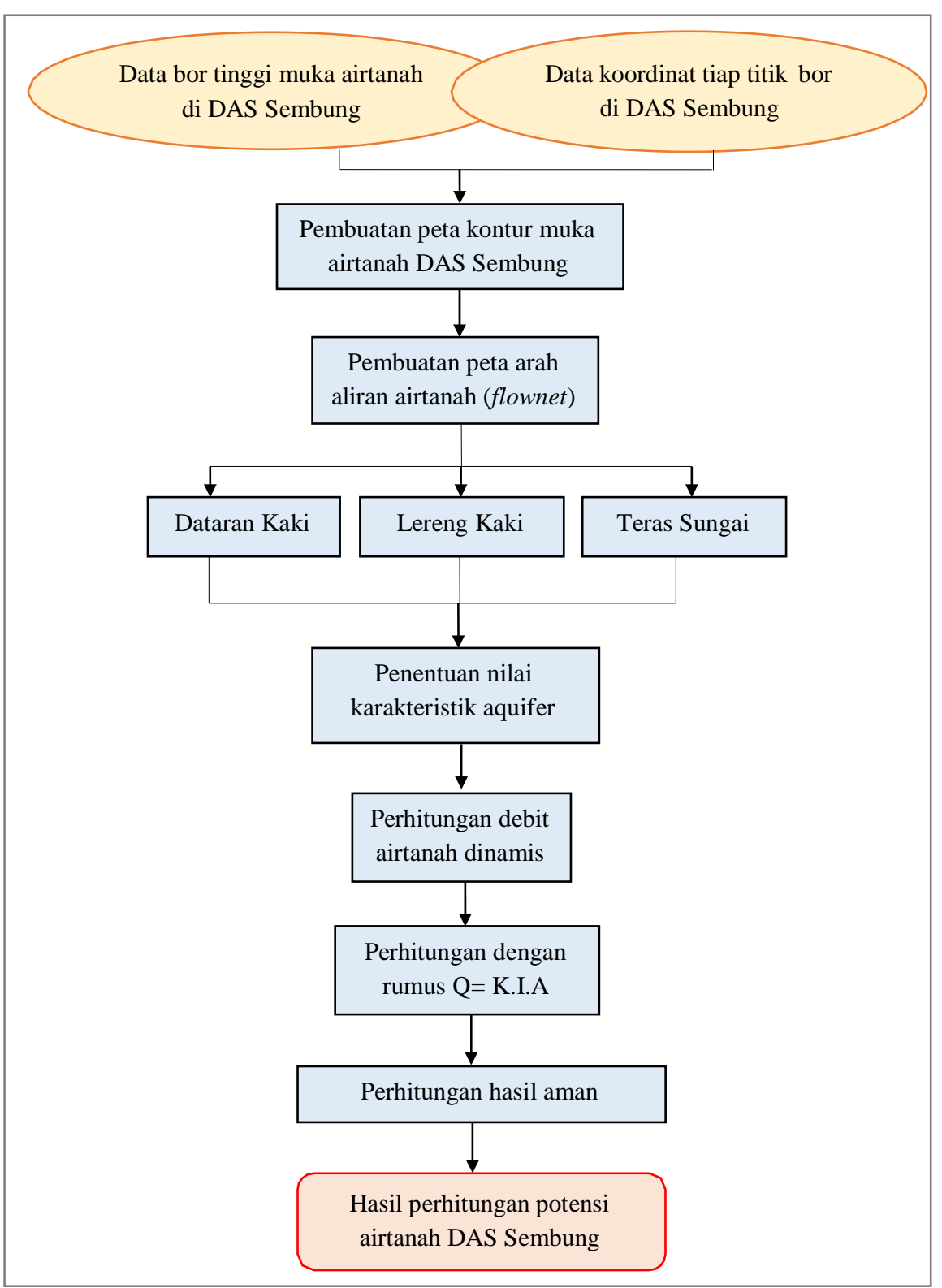

\subsection{Neraca Air}

\section{Gambar 3.2. Diagram Alir Perhitungan Potensi Airtanah}

Perhitungan neraca air dilakuakn menggunakan data curah hujan bulanan dan evapotranspirasi potensial. Curah hujan bulanan didapatkan melalui perhitungan hujan wilayah dari data rata-rata bulanan selama sepuluh tahun (2001-2010). Evapotranspirasi potensial dihitung menggunakan konsep Thornwaite-Matter. Hasil perhitungan neraca air adalah nilai S (surplus air), D (defisit air), dan Ro (limpasan permukaan) (Gambar 3.3). Nilai-nilai tersebut dapat digunakan untuk menganalisis ketersediaan air di DAS Sembung. 


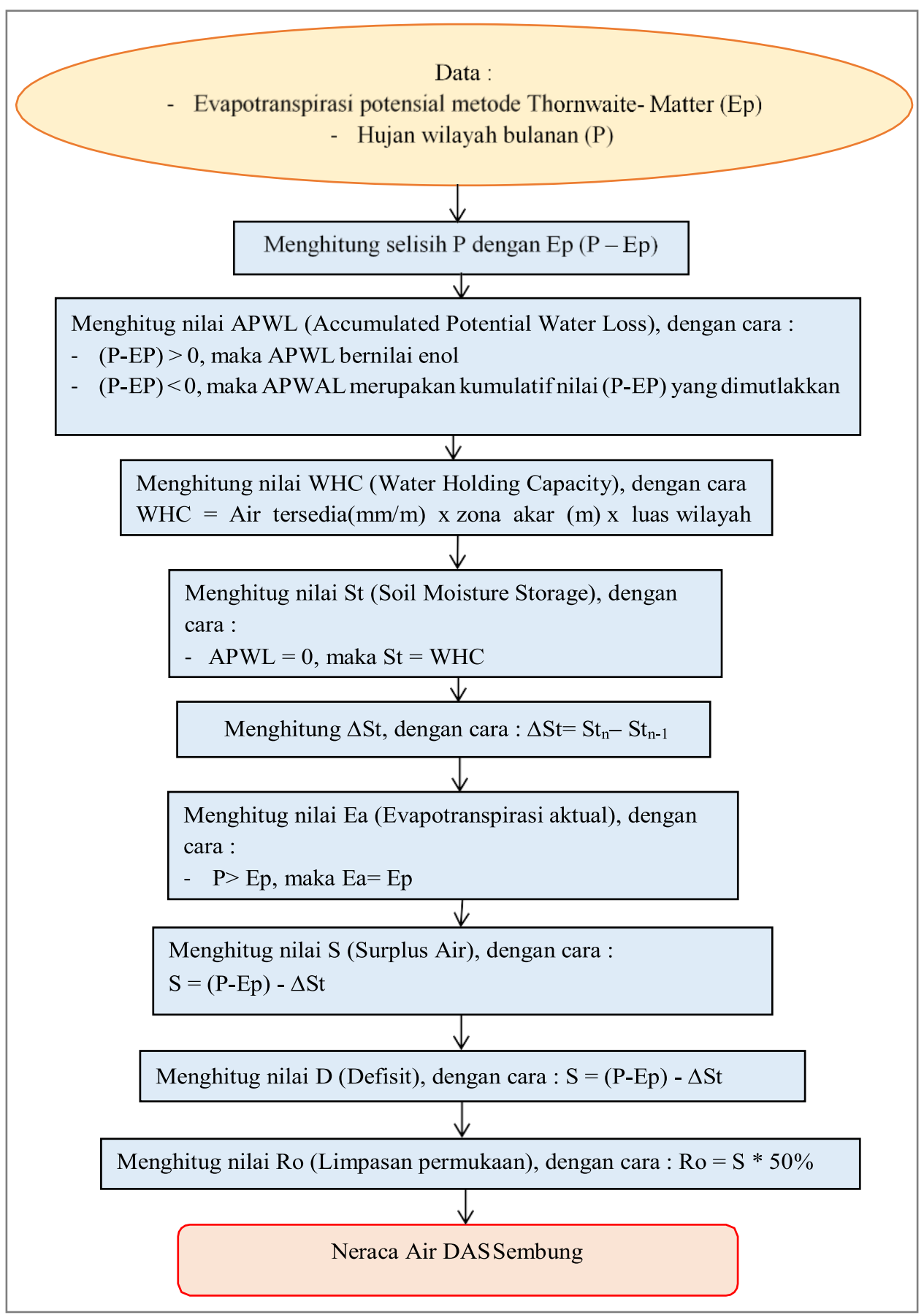

Gambar 3.3. Diagram Alir Pembuatan Neraca Air

\subsection{Perhitungan Kebutuhan Air Domestik}

Perhitungan kebutuhan air domestik dapat dihitung melalui pendekatan jumlah penduduk pedesaan (Gambar 3.4). Wilayah kajian termasuk kedalam wilayah pedesaan ( $\mathrm{Qr}=100)$ sehingga menggunakan perhitungan ketetapan penggunaan air pedesaan 


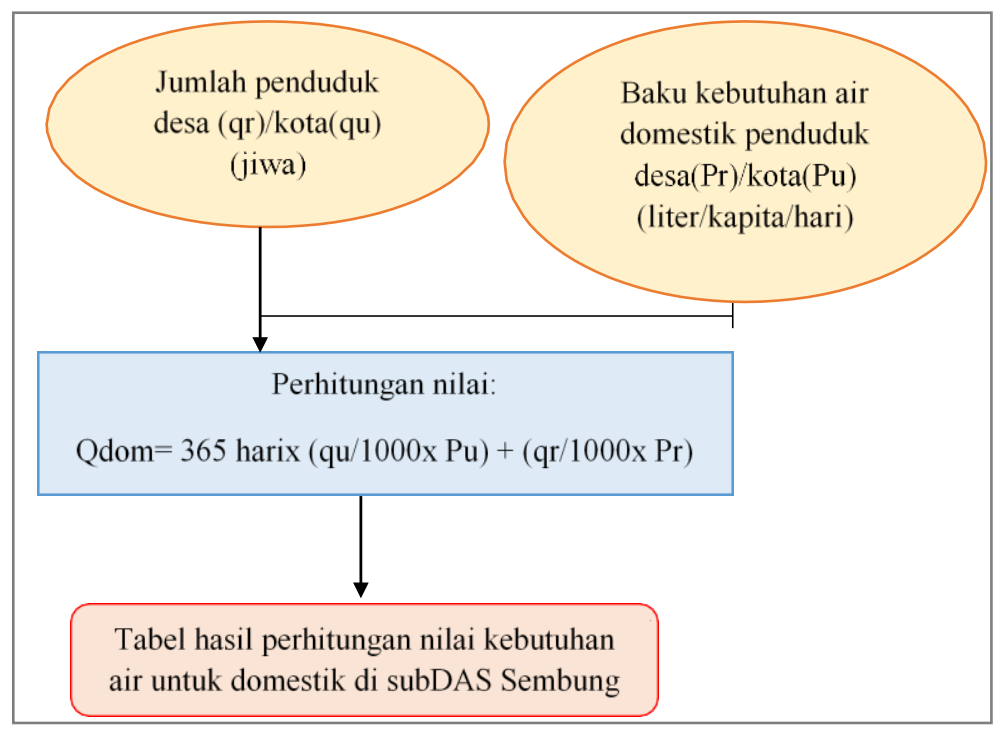

Gambar 3.4 Perhitungan Kebutuhan Air Domestik

\subsection{Perhitungan Kebutuhan Air Ternak}

Kebutuahan air untuk ternak ditentukan oleh besar kecilnya peternakan. Hal ini berpengaruh terhadap kebutuhan air, seperti peternakan skala besar dengan jumlah ternak yang banyak maka konsumsi air akan lebih besar. Selain itu, Jenis hewan ternak juga memengaruhi kebutuhan air (Gambar 3.5).

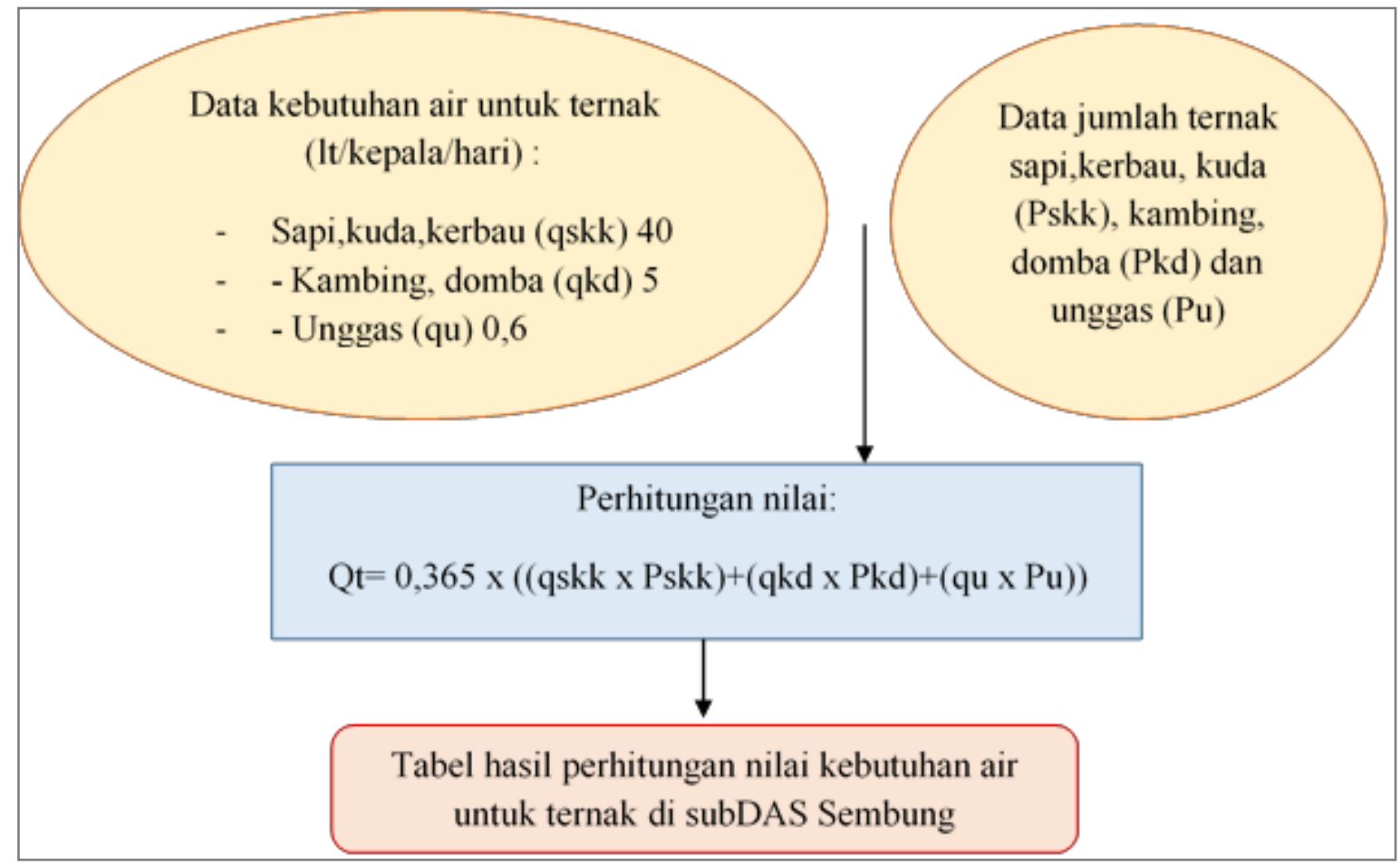

Gambar 3.5. Perhitungan Kebutuhan Air Ternak 


\subsection{Perhitungan Kebutuhan Air Industri}

Kebutuhan air industri ditentukan berdasarkan jumlah tenaga kerja yang bekerja di Sub DAS sembung dan jumlah hari kerja (Gambar 3.6). Hal ini dijelaskan oleh rumus berikut:

\section{Qid = 0,5(Total Tenaga Kerja x Jumlah Hari Kerja)}

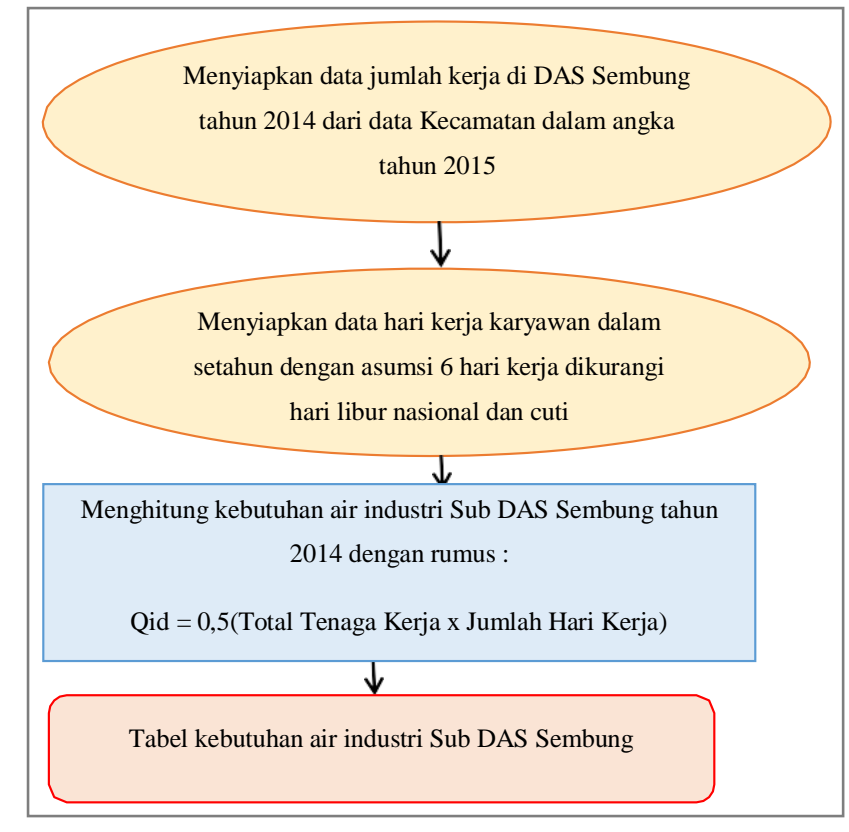

Gambar 3.6. Perhitungan Kebutuhan Air Industri

\subsection{Perhitungan Kebutuhan Air Pertanian}

Kebutuhan air irigasi ditentukan oleh luas sawah irigasi (A) dan masa tanam (Tn) (Gambar 3.7). Masa tanam padi diasumsikan 100 hari. Kebutuhann air pertanian dihitung berdasarkan rumus kebutuhan air irigasi (Qi), yaitu :

\section{$\mathrm{Qi}=\mathrm{A}(\mathrm{qs} / \mathbf{1 0 0 0}) \times \mathrm{Tn} \times 86400$}

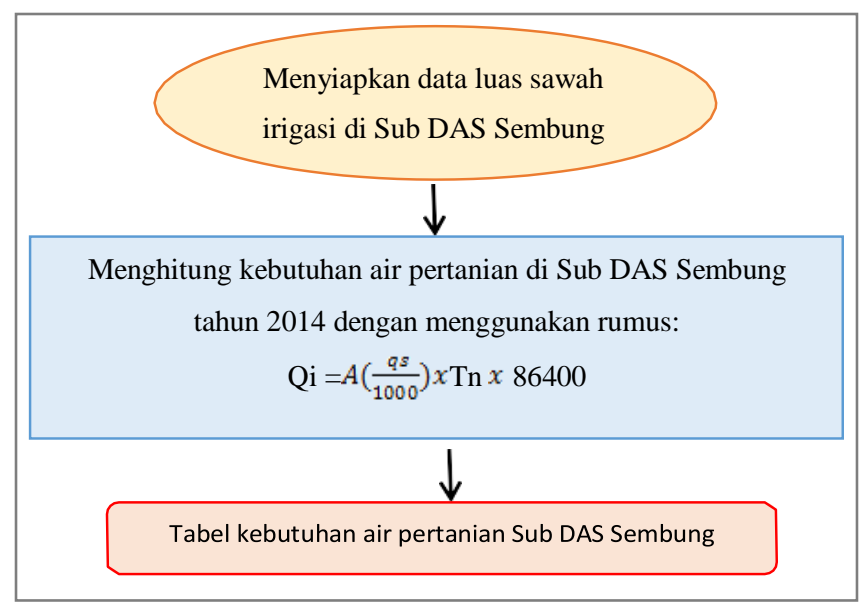

Gambar 3.7. Perhitungan Kebutuhan Air Pertanian 


\subsection{Perhitungan Kebutuhan Air Perikanan}

Kebutuhan air untuk perikanan dihitung berdasarkan data kebutuhan air untuk pembilasan dan data luas kolam ikan (Gambar 3.8). Setiap jenis budidaya ikan akan berbeda pola penggunaan airnya.

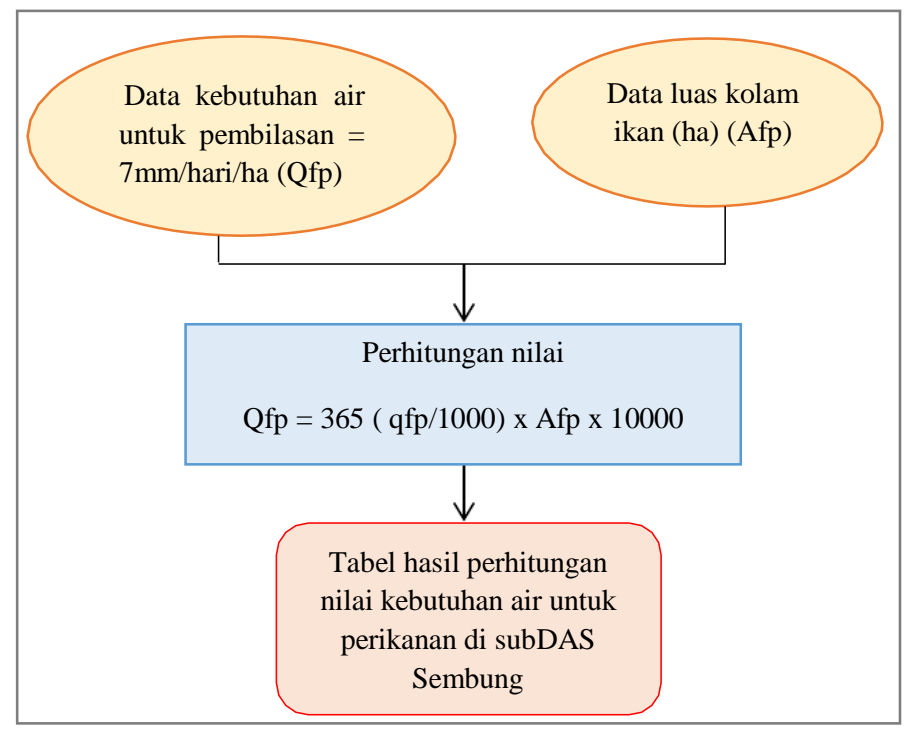

Gambar 3.8. Perhitungan Kebutuhan Air Perikanan

\subsection{Kekritisan Air}

Tingkat kekritisan air didapatkan dengan membandingkan jumlah ketersediaan air dengan jumlah kebutuhan air di DAS Sembung (Tabel 3.1 dan Gambar 3.9). Ketersediaan air didapatkan dari jumlah ketersediaaan air meteorologis, air hidrologis dan airtanah. Jumlah kebutuhan air di DAS Sembung merupakan total jumlah kebutuhan air domestik, air irigasi, perikanan, peternakan, dan industri. Desa dalam setiap bentuklahan merupakan unit analisis pengklasifikasian tingkat kekrritisan air di DAS Sembung.

Tabel 3.1 Kriteria Kekritisan Air

\begin{tabular}{|l|l|}
\hline Kriteria & Kekritisan AIr \\
\hline Mendekati Kritis & $50 \%-75 \%$ \\
\hline Keadaan Kritis & $70 \%-100 \%$ \\
\hline Telah Kritis & $.100 \%$ \\
\hline
\end{tabular}




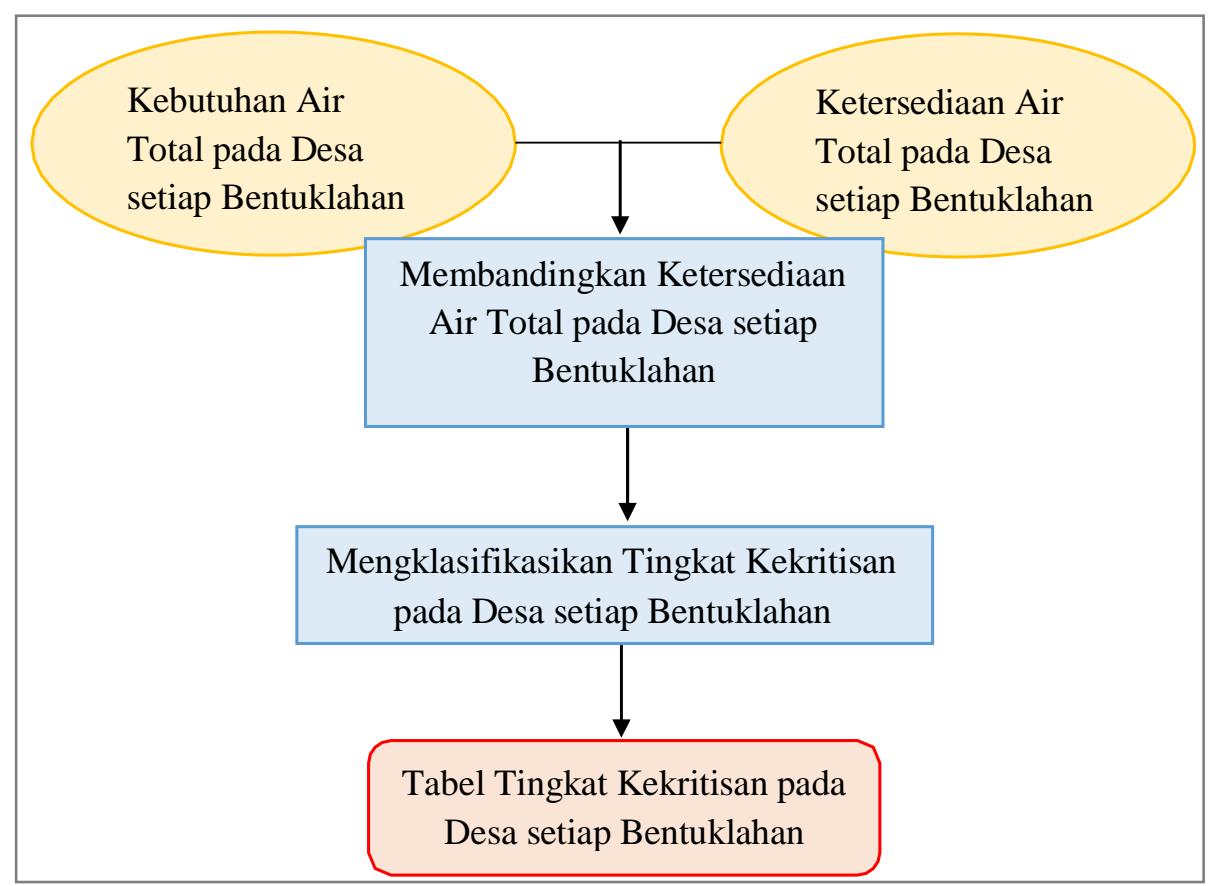

Gambar 3.9. Perhitungan Tingkat Kekritisan Air

\section{HASIL DAN PEMBAHASAN}

\subsection{Ketersediaan Air Meteorologis}

\section{a. Curah Hujan}

Hujan bulanan di DAS Sembung dapat dilihat di Tabel 4.1. Data hujan tersebut menunjukkan bahwa DAS Sembung dipengaruhi oleh proses muson dan orografis. Puncak hujan di seluruh wilayah di DAS Sembung berada pada bulan Januari yang mencapai 300 - 400 $\mathrm{mm} /$ bulan. Musim penghujan diawali pada bulan Oktober hingga berakhir pada April atau Mei di beberapa wilayah. Musim kemarau dimulai pada Juni yang mencapai puncaknya di bulan Agustus atau September. Desa-desa yang berada di lereng kaki gunungapi cenderung memiliki surah hujan yang lebih besar dibanding daerah lain karena daerah ini dipengaruhi oleh hujan orografis. Desa Pakem Binangun bahkan memiliki hujan senilai $417.7 \mathrm{~mm} / \mathrm{bulan}$ pada bulan Januari. Secara umum, desa-desa di DAS Sembung memiliki curah hujan tinggi pada musim penghujan (OktoberMaret). Hal ini tentunya merupakan sumberdaya yang baik bagi kebutuhan air di DAS Sembung.

Tabel 4.1. Curah Hujan Rerata 10 Tahun (2001-2010)

\begin{tabular}{|c|c|c|c|c|c|c|c|c|c|c|c|c|c|c|}
\hline BL & DESA & JAN & FEB & MAR & APR & MEI & JUN & JUL & AGS & SEP & OKT & NOV & DES & $\begin{array}{c}\text { Jumlah } \\
(\mathrm{mm} / \mathrm{th})\end{array}$ \\
\hline \multirow{3}{*}{$\begin{array}{c}\text { Lereng } \\
\text { Kaki } \\
\text { Gunungapi }\end{array}$} & $\begin{array}{c}\text { Pakem } \\
\text { Binangun }\end{array}$ & 417.7 & 366.9 & 339.2 & 262.2 & 109.2 & 39.3 & 12.5 & 7.1 & 7.9 & 176.7 & 280.2 & 302.8 & 2321.7 \\
\hline & Umbulmartani & 382.8 & 342.3 & 305.9 & 238.2 & 98.4 & 37.6 & 11.2 & 7.1 & 10.6 & 157.0 & 239.7 & 266.7 & 2097.3 \\
\hline & Sardonoharjo & 360.0 & 320.0 & 270.0 & 215.0 & 88.0 & 37.0 & 10.0 & 7.1 & 11.9 & 147.9 & 211.0 & 243.0 & 1920.9 \\
\hline
\end{tabular}




\begin{tabular}{|c|c|c|c|c|c|c|c|c|c|c|c|c|c|c|}
\hline BL & DESA & JAN & FEB & MAR & APR & MEI & JUN & JUL & AGS & SEP & OKT & NOV & DES & $\begin{array}{l}\text { Jumlah } \\
(\mathrm{mm} / \mathrm{th})\end{array}$ \\
\hline & Suko Harjo & 243.0 & 244.4 & 205.4 & 194.6 & 64.3 & 33.2 & 8.4 & 7.1 & 12.2 & 148.4 & 183.4 & 241.5 & 1585.9 \\
\hline \multirow{6}{*}{$\begin{array}{c}\text { Dataran } \\
\text { Kaki } \\
\text { Gunungapi }\end{array}$} & Wedomartani & 322.8 & 320.0 & 269.7 & 205.0 & 88.0 & 36.5 & 10.5 & 7.1 & 14.5 & 136.5 & 195.0 & 251.0 & 1856.6 \\
\hline & Sardonoharjo & 345.0 & 320.0 & 270.0 & 215.0 & 88.0 & 36.5 & 10.0 & 7.1 & 13.0 & 143.0 & 203.0 & 243.0 & 1893.6 \\
\hline & Suko Harjo & 341.8 & 320.0 & 270.0 & 210.0 & 89.0 & 36.5 & 10.0 & 7.1 & 12.9 & 143.3 & 203.0 & 251.0 & 1894.6 \\
\hline & Sinduharjo & 330.0 & 319.9 & 270.0 & 206.1 & 88.0 & 36.6 & 10.0 & 7.1 & 13.0 & 143.0 & 195.0 & 243.0 & 1861.8 \\
\hline & $\begin{array}{c}\text { Condong } \\
\text { Catur }\end{array}$ & 315.0 & 320.0 & 270.0 & 205.0 & 88.0 & 37.0 & 11.0 & 7.2 & 16.0 & 130.0 & 195.0 & 259.0 & 1853.2 \\
\hline & Maguwoharjo & 327.8 & 320.0 & 270.0 & 205.0 & 88.0 & 37.0 & 10.6 & 7.2 & 16.0 & 130.0 & 195.0 & 282.3 & 1888.9 \\
\hline \multirow{3}{*}{$\begin{array}{l}\text { Teras } \\
\text { Sungai }\end{array}$} & Wedomartani & 322.5 & 320.0 & 270.0 & 205.0 & 88.0 & 36.5 & 10.0 & 7.1 & 14.5 & 136.5 & 195.0 & 251.0 & 1856.1 \\
\hline & Sinduharjo & 330.0 & 320.0 & 270.0 & 205.0 & 88.0 & 36.6 & 10.0 & 7.1 & 13.0 & 143.0 & 195.0 & 243.0 & 1860.7 \\
\hline & Maguwoharjo & 322.5 & 320.0 & 270.0 & 205.0 & 88.0 & 37.0 & 10.0 & 7.2 & 16.0 & 130.0 & 195.0 & 251.0 & 1851.7 \\
\hline
\end{tabular}

\section{b. Evapotranspirasi}

Evapotranspirasi potensial dan aktual di DAS Sembung dapat dilihat di Tabel 4.2. Evapotranspirasi potensial (Ep) dihitung menggunanakan metode Thornwaite-Matter, sedangkan evapotranspirasi aktual (Ea) dihitung menggunakan metode neraca air meteorlogis. Tabel 4.3 menujukkan bahwa ketika musim penghujan maka nilai Ea akan sama dengan nilai Ep. Hal ini terjadi karena lengas air berada dalam kandunan optimum. Sementara itu, nilai Ea akan lebih kecil dari Ep ketika musim kemarau terjadi. Hal ini karena Ea dihitung berdasarkan asumsi kondisi lengas tana saat musim kemarau terjadi, sedangkan Ep menggunakan asumsi ketika simpanan lengas tenan tetap optimum. Nilai Ea maupun Ep tersebut sekaligus menguatkan bukti bahwa musim penghujan di DAS Sembung terjadi ketika bulan Oktober-April, sedangkan musim kemarau terjadi ketika bulan Mei-September. Nilai evapotranspirasi dan curah hujan ini dapat digunakan untuk menghitung ketersediaan air meteorologis yang dapat menunjukka nilai surplus maupun defisit di setiap bulannya.

Tabel 4.2. Evapotrnaspirasi Potensial Metode Thornwaite-Matter

\begin{tabular}{|c|c|c|c|c|c|c|c|c|c|c|c|c|c|c|}
\hline BL & DESA & JAN & FEB & MAR & APR & MEI & JUN & JUL & AGS & SEP & OKT & NOV & DES & $\begin{array}{r}\text { Jumlah } \\
\text { (mm/th) }\end{array}$ \\
\hline \multirow{4}{*}{$\begin{array}{c}\text { Lereng } \\
\text { Kaki } \\
\text { Gunungapi }\end{array}$} & $\begin{array}{c}\text { Pakem } \\
\text { Binangun }\end{array}$ & 113.0 & 102.5 & 111.0 & 105.5 & 96.4 & 91.5 & 84.3 & 75.4 & 84.1 & 100.3 & 99.7 & 88.8 & 1152.4 \\
\hline & Umbulmartani & 113.0 & 102.5 & 111.0 & 105.5 & 96.4 & 91.5 & 84.3 & 75.4 & 84.1 & 100.3 & 99.7 & 88.8 & 1152.4 \\
\hline & Sardonoharjo & 114.8 & 102.1 & 110.6 & 105.2 & 95.9 & 91.0 & 83.8 & 77.1 & 86.0 & 102.6 & 105.3 & 95.0 & 1169.5 \\
\hline & Suko Harjo & 113.2 & 102.4 & 110.9 & 105.5 & 96.3 & 91.4 & 85.5 & 75.4 & 84.3 & 100.6 & 101.0 & 91.2 & 1157.8 \\
\hline \multirow{5}{*}{$\begin{array}{c}\text { Dataran } \\
\text { Kaki } \\
\text { Gunungapi }\end{array}$} & Wedomartani & 118.0 & 107.3 & 116.3 & 110.5 & 101.8 & 95.4 & 90.7 & 80.5 & 90.0 & 107.6 & 106.9 & 98.3 & 1223.2 \\
\hline & Sardonoharjo & 117.7 & 102.4 & 111.3 & 104.9 & 95.4 & 91.5 & 88.7 & 80.3 & 89.6 & 106.8 & 104.9 & 94.5 & 1187.9 \\
\hline & Suko Harjo & 117.4 & 105.9 & 115.2 & 104.6 & 98.7 & 94.7 & 88.3 & 80.0 & 89.2 & 106.5 & 104.6 & 94.2 & 1199.5 \\
\hline & Sinduharjo & 117.3 & 105.7 & 116.5 & 105.5 & 102.2 & 95.8 & 88.1 & 79.7 & 89.0 & 106.3 & 104.4 & 94.0 & 1204.7 \\
\hline & $\begin{array}{l}\text { Condong } \\
\text { Catur }\end{array}$ & 121.9 & 113.2 & 122.6 & 109.8 & 100.8 & 100.6 & 92.2 & 84.4 & 94.4 & 113.0 & 109.6 & 99.7 & 1262.2 \\
\hline
\end{tabular}




\begin{tabular}{|c|c|c|c|c|c|c|c|c|c|c|c|c|c|c|}
\hline BL & DESA & JAN & FEB & MAR & APR & MEI & JUN & JUL & AGS & SEP & OKT & NOV & DES & $\begin{array}{c}\text { Jumlah } \\
(\mathbf{m m} / \text { th })\end{array}$ \\
\hline & Maguwoharjo & 122.1 & 113.4 & 116.2 & 110.0 & 101.0 & 95.2 & 92.5 & 84.7 & 94.7 & 113.2 & 109.8 & 99.9 & 1252.6 \\
\hline \multirow{2}{*}{$\begin{array}{c}\text { Teras } \\
\text { Sungai }\end{array}$} & Wedomartani & 117.9 & 107.3 & 116.3 & 110.5 & 101.8 & 95.4 & 90.2 & 80.3 & 89.7 & 107.3 & 106.9 & 97.8 & 1221.4 \\
\cline { 2 - 39 } & Sinduharjo & 117.2 & 107.5 & 116.4 & 110.7 & 102.0 & 95.7 & 87.9 & 79.5 & 88.8 & 106.2 & 104.2 & 93.8 & 1209.9 \\
\hline
\end{tabular}

Tabel 4.3 Evapotranspirasi Aktual Metode Neraca Air

\begin{tabular}{|c|c|c|c|c|c|c|c|c|c|c|c|c|c|c|}
\hline BL & DESA & JAN & FEB & MAR & APR & MEI & JUN & JUL & AGS & SEP & OKT & NOV & DES & $\begin{array}{r}\text { Jumlah } \\
\text { (mm/th) }\end{array}$ \\
\hline \multirow{4}{*}{$\begin{array}{c}\text { Lereng } \\
\text { Kaki } \\
\text { Gunungapi }\end{array}$} & $\begin{array}{l}\text { Pakem } \\
\text { Binangun }\end{array}$ & 113.0 & 102.5 & 111.0 & 105.5 & 96.4 & 58.2 & 14.1 & 7.1 & 7.9 & 100.3 & 99.7 & 88.8 & 904.4 \\
\hline & Umbulmartani & 113.0 & 102.5 & 111.0 & 105.5 & 96.4 & 56.8 & 12.7 & 7.1 & 10.6 & 100.3 & 99.7 & 88.8 & 904.3 \\
\hline & Sardonoharjo & 114.8 & 102.1 & 110.6 & 105.2 & 88.0 & 37.0 & 10.0 & 7.1 & 11.9 & 102.6 & 105.3 & 95.0 & 889.6 \\
\hline & Suko Harjo & 113.2 & 102.4 & 110.9 & 105.5 & 70.7 & 33.2 & 8.4 & 7.1 & 12.2 & 100.6 & 101.0 & 91.2 & 856.4 \\
\hline \multirow{6}{*}{$\begin{array}{c}\text { Dataran } \\
\text { Kaki } \\
\text { Gunungapi }\end{array}$} & Wedomartani & 118.0 & 107.3 & 116.3 & 110.5 & 92.2 & 36.7 & 10.5 & 7.1 & 14.5 & 107.6 & 106.9 & 98.3 & 926.0 \\
\hline & Sardonoharjo & 117.7 & 102.4 & 111.3 & 104.9 & 88.0 & 36.5 & 10.0 & 7.1 & 13.0 & 106.8 & 104.9 & 94.5 & 897.0 \\
\hline & Suko Harjo & 117.4 & 105.9 & 115.2 & 104.6 & 94.3 & 38.3 & 10.0 & 7.1 & 12.9 & 106.5 & 104.6 & 94.2 & 911.0 \\
\hline & Sinduharjo & 117.3 & 105.7 & 116.5 & 105.5 & 90.8 & 36.6 & 10.0 & 7.1 & 13.0 & 106.3 & 104.4 & 94.0 & 907.3 \\
\hline & $\begin{array}{l}\text { Condong } \\
\text { Catur }\end{array}$ & 121.9 & 113.2 & 122.6 & 109.8 & 88.0 & 37.0 & 11.0 & 7.2 & 16.0 & 113.0 & 109.6 & 99.7 & 949.0 \\
\hline & Maguwoharjo & 122.1 & 113.4 & 116.2 & 110.0 & 88.2 & 37.0 & 10.6 & 7.2 & 16.0 & 113.2 & 109.8 & 99.9 & 943.6 \\
\hline \multirow{3}{*}{$\begin{array}{l}\text { Teras } \\
\text { Sungai }\end{array}$} & Wedomartani & 117.9 & 107.3 & 116.3 & 110.5 & 90.8 & 36.5 & 10.0 & 7.1 & 14.5 & 107.3 & 106.9 & 97.8 & 923.0 \\
\hline & Sinduharjo & 117.2 & 107.5 & 116.4 & 110.7 & 88.3 & 36.6 & 10.0 & 7.1 & 13.0 & 106.2 & 104.2 & 93.8 & 910.9 \\
\hline & Maguwoharjo & 122.4 & 107.1 & 100.6 & 110.3 & 88.3 & 37.0 & 10.0 & 7.2 & 16.0 & 113.6 & 110.2 & 100.4 & 922.9 \\
\hline
\end{tabular}

\section{c. Surplus dan Defisit Neraca Air}

DAS Sembung memiliki karakteristik musim penghujan pada bulan Oktober-April dan musim kemarau pada bulan Mei-Sepetember. Kondisi ini memengaruhi ketersediaan air meteorologis di wilayah ini seperti dapat dilihat pada tabel 4.44. DAS Sembung mengalami surplus air pada musim penghujan dan defisit air pada musim kemarau. Ketika musim penghujan mencapai puncak pada bulan Januari, surplus air di DAS Sembung mencapai 200-300 mm. Surplus air ini tersimpan berupa infiltasi masuk ke air tanah, tersimpan sebagai lengas tanah, dan apabila tanah sudah jenuh akan menjadi limpasan permukaan. Surplus air inilah yang dapat digunakan tanaman untuk tumbuh. Defisit air yang terjadi (Tabel 4.5) pada musim kemarau dapat digunakan untuk menentukan kebutuhan air untuk irigasi pertanian agar tanaman dapat tumbuh.

Tabel 4.4 Surplus Neraca Air DAS Sembung

\begin{tabular}{|c|c|c|c|c|c|c|c|c|c|c|c|c|c|c|c|c|}
\hline DESA & BL & JAN & FEB & MAR & APR & MEI & JUN & JUL & AGS & SEP & OKT & NOV & DES & jumlah & $\begin{array}{l}\text { Luas } \\
\text { (m2) }\end{array}$ & Vol (m3) \\
\hline \multirow{5}{*}{$\begin{array}{c}\text { Lereng } \\
\text { Kaki } \\
\text { Gunungapi }\end{array}$} & $\begin{array}{c}\text { Pakem } \\
\text { Binangun }\end{array}$ & 304.7 & 264.4 & 228.2 & 156.7 & 12.9 & 0.0 & 0.0 & 0.0 & 0.0 & 56.0 & 180.5 & 214.0 & 1417.4 & $1,762,993$ & $2,498,788$ \\
\hline & Umbulmartani & 269.7 & 239.8 & 194.9 & 132.6 & 2.0 & 0.0 & 0.0 & 0.0 & 0.0 & 36.0 & 140.1 & 177.9 & 1193.1 & $2,037,388$ & $2,430,753$ \\
\hline & Sardonoharjo & 245.2 & 217.9 & 159.4 & 109.8 & 0.0 & 0.0 & 0.0 & 0.0 & 0.0 & 45.3 & 105.7 & 148.0 & 1031.2 & 51,512 & 53,121 \\
\hline & Suko Harjo & 129.8 & 141.9 & 94.4 & 89.1 & 0.0 & 0.0 & 0.0 & 0.0 & 0.0 & 41.4 & 82.4 & 150.4 & 729.5 & $1,157,613$ & 844,436 \\
\hline & Wedomartani & 204.8 & 212.7 & 153.3 & 94.5 & 0.0 & 0.0 & 0.0 & 0.0 & 0.0 & 24.5 & 88.1 & 152.7 & 930.6 & $1,061,666$ & 987,978 \\
\hline
\end{tabular}




\begin{tabular}{|c|c|c|c|c|c|c|c|c|c|c|c|c|c|c|c|c|}
\hline DESA & BL & JAN & FEB & MAR & APR & MEI & JUN & JUL & AGS & SEP & OKT & NOV & DES & jumlah & $\begin{array}{l}\text { Luas } \\
\text { (m2) }\end{array}$ & Vol (m3) \\
\hline \multirow{5}{*}{$\begin{array}{c}\text { Dataran } \\
\text { Kaki } \\
\text { Gunungapi }\end{array}$} & Sardonoharjo & 227.3 & 217.6 & 158.7 & 110.1 & 0.0 & 0.0 & 0.0 & 0.0 & 0.0 & 36.2 & 98.1 & 148.5 & 996.6 & 54,667 & 54,481 \\
\hline & Suko Harjo & 224.3 & 214.1 & 154.8 & 105.4 & 0.0 & 0.0 & 0.0 & 0.0 & 0.0 & 29.7 & 98.4 & 156.8 & 983.6 & $1,025,533$ & $1,008,682$ \\
\hline & Sinduharjo & 212.7 & 214.2 & 153.5 & 100.6 & 0.0 & 0.0 & 0.0 & 0.0 & 0.0 & 33.9 & 90.6 & 149.0 & 954.5 & 405,368 & 386,909 \\
\hline & $\begin{array}{l}\text { Condong } \\
\text { Catur }\end{array}$ & 193.1 & 206.8 & 147.4 & 95.2 & 0.0 & 0.0 & 0.0 & 0.0 & 0.0 & 16.9 & 85.4 & 159.3 & 904.2 & 3,137 & 2,836 \\
\hline & Maguwoharjo & 205.7 & 206.6 & 153.8 & 95.0 & 0.0 & 0.0 & 0.0 & 0.0 & 0.0 & 16.6 & 85.2 & 182.4 & 945.3 & 223,475 & 211,254 \\
\hline \multirow{3}{*}{$\begin{array}{l}\text { Teras } \\
\text { Sungai }\end{array}$} & Wedomartani & 204.6 & 212.7 & 153.7 & 94.5 & 0.0 & 0.0 & 0.0 & 0.0 & 0.0 & 26.4 & 88.1 & 153.2 & 933.1 & 289,332 & 269,989 \\
\hline & Sinduharjo & 212.8 & 212.5 & 153.6 & 94.3 & 0.0 & 0.0 & 0.0 & 0.0 & 0.0 & 36.5 & 90.8 & 149.2 & 949.8 & 33,141 & 31,476 \\
\hline & Maguwoharjo & 200.1 & 212.9 & 169.4 & 94.7 & 0.0 & 0.0 & 0.0 & 0.0 & 0.0 & 16.1 & 84.8 & 150.6 & 928.7 & 32,904 & 30,559 \\
\hline
\end{tabular}

Tabel 4.5 Defisit Neraca Air DAS Sembung

\begin{tabular}{|c|c|c|c|c|c|c|c|c|c|c|c|c|c|c|c|c|}
\hline BL & DESA & JAN & FEB & MAR & APR & MEI & JUN & JUL & AGS & SEP & OKT & NOV & DES & jumlah & $\begin{array}{l}\text { Luas } \\
\text { (m2) }\end{array}$ & Vol (m3) \\
\hline \multirow{4}{*}{$\begin{array}{c}\text { Lereng } \\
\text { Kaki } \\
\text { Gunungapi }\end{array}$} & $\begin{array}{c}\text { Pakem } \\
\text { Binangun }\end{array}$ & 0.0 & 0.0 & 0.0 & 0.0 & 0.0 & 33.3 & 70.2 & 68.3 & 76.2 & 0.0 & 0.0 & 0.0 & 248.0 & $1,762,993$ & 437,230 \\
\hline & Umbulmartani & 0.0 & 0.0 & 0.0 & 0.0 & 0.0 & 34.7 & 71.6 & 68.3 & 73.5 & 0.0 & 0.0 & 0.0 & 248.1 & $2,037,388$ & 505,540 \\
\hline & Sardonoharjo & 0.0 & 0.0 & 0.0 & 0.0 & 7.9 & 54.0 & 73.8 & 70.1 & 74.1 & 0.0 & 0.0 & 0.0 & 279.9 & 51,512 & 14,417 \\
\hline & Suko Harjo & 0.0 & 0.0 & 0.0 & 0.0 & 25.6 & 58.2 & 77.1 & 68.3 & 72.2 & 0.0 & 0.0 & 0.0 & 301.4 & $1,157,613$ & 348,857 \\
\hline \multirow{6}{*}{$\begin{array}{c}\text { Dataran } \\
\text { Kaki } \\
\text { Gunungapi }\end{array}$} & Wedomartani & 0.0 & 0.0 & 0.0 & 0.0 & 9.5 & 58.7 & 80.2 & 73.4 & 75.5 & 0.0 & 0.0 & 0.0 & 297.2 & $1,061,666$ & 315,574 \\
\hline & Sardonoharjo & 0.0 & 0.0 & 0.0 & 0.0 & 7.4 & 55.0 & 78.7 & 73.3 & 76.6 & 0.0 & 0.0 & 0.0 & 290.9 & 54,667 & 15,904 \\
\hline & Suko Harjo & 0.0 & 0.0 & 0.0 & 0.0 & 4.4 & 56.4 & 78.3 & 72.9 & 76.3 & 0.0 & 0.0 & 0.0 & 288.4 & $1,025,533$ & 295,778 \\
\hline & Sinduharjo & 0.0 & 0.0 & 0.0 & 0.0 & 11.4 & 59.2 & 78.1 & 72.6 & 76.0 & 0.0 & 0.0 & 0.0 & 297.4 & 405,368 & 120,553 \\
\hline & $\begin{array}{c}\text { Condong } \\
\text { Catur }\end{array}$ & 0.0 & 0.0 & 0.0 & 0.0 & 12.8 & 63.6 & 81.2 & 77.2 & 78.4 & 0.0 & 0.0 & 0.0 & 313.2 & 3,137 & 982 \\
\hline & Maguwoharjo & 0.0 & 0.0 & 0.0 & 0.0 & 12.8 & 58.2 & 81.9 & 77.5 & 78.7 & 0.0 & 0.0 & 0.0 & 309.1 & 223,475 & 69,069 \\
\hline \multirow{3}{*}{$\begin{array}{c}\text { Teras } \\
\text { Sungai }\end{array}$} & Wedomartani & 0.0 & 0.0 & 0.0 & 0.0 & 11.0 & 58.9 & 80.2 & 73.1 & 75.2 & 0.0 & 0.0 & 0.0 & 298.4 & 289,332 & 86,347 \\
\hline & Sinduharjo & 0.0 & 0.0 & 0.0 & 0.0 & 13.7 & 59.1 & 77.9 & 72.4 & 75.8 & 0.0 & 0.0 & 0.0 & 299.0 & 33,141 & 9,909 \\
\hline & Maguwoharjo & 0.0 & 0.0 & 0.0 & 0.0 & 13.1 & 58.3 & 83.0 & 78.0 & 79.1 & 0.0 & 0.0 & 0.0 & 311.6 & 32,904 & 10,252 \\
\hline
\end{tabular}

\subsection{Ketersediaan Air Permukaan}

\section{a. Limpasan Permukaan}

Ketersediaan air permukaan DAS Sembung dapat dilihat melalui nilai run off (limpasan permukaan) dari hasil perhitungan neraca air meteorologis tabel 4.4. Nilai tersebut didapat melalui estimasi sejumlah 50\% dari nilai surplus yang ada pada bulan sebelumnya. Estimasi tersebut didasarkan bahwa surplus air yang ada sebagian ada yang mengalami perkolasi menjadi air tanah, sebagian ,mengalami infiltasi menjadi lengas tanah, dan sisanya menjadi limpasan permukaan yang menjadi ketersediaan air permukaan.

Tabel 4.6 menunjukkan bahwa jumlah volume limpasan permukaan setiap tahun merupakan fungsi perkalian dari tebal limpasan dengan luas wilayah. Oleh karena itu, Desa Pakem Binangun dan Umbulmartani yang memiliki luas wilayah dan tebal limpasan paling tinggi memiliki volume limpsan paling tinggi pula. Limpasan permukaan ini nantinya akan mengalir sebagai input sungai maupun saluran irigasi yang telah ada. Oleh karena itu, hal utama yang perlu 
diperhatikan adalah bagaimana menyimpan air hujan yang berubah menjadi limpasan permukaan ini karena kapaitas tanah untuk menyimpan dalam infiltrasi maupun perkolasi tentunya memiliki keterbatasan.

Air limpasan permukaan yang tidak ditampung akan mengalir kesungai dan bermuara di lautan. Usaha penyimpanan air permukaan di DAS Sembung sudah dilakukan di wilayah hilir dengan adanya Embung Tambakbayan. Sistem embung ini akan menyimpan aliran dari sungai untuk dipergnakan dalam berbagai hal seperti irigasi. Permasalahannya adalah embung ini terletak di hilir yang jauh dari lokasi hulu. Air limpsan yang ada di hulu maupun tengah tidak dapat dimanfaatkan untuk kepentingan masyarakat sekitar. Oleh karena itu, pembuatann penampungan air hujan sederhana dapat dilakukan untuk melakukan koservasi terhadap air.

Tabel 4.6 Limpasan Permukaan Metode Neraca Air

\begin{tabular}{|c|c|c|c|c|c|c|c|c|c|c|c|c|c|c|c|c|}
\hline BL & DESA & JAN & FEB & MAR & APR & MEI & JUN & JUL & AGS & SEP & OKT & NOV & DES & $\begin{array}{l}\text { Jumlah } \\
\text { (mm/th) }\end{array}$ & $\begin{array}{l}\text { Luas } \\
(\mathrm{m} 2)\end{array}$ & $\begin{array}{c}\begin{array}{c}\text { Volume } \\
\text { (m3) }\end{array} \\
\end{array}$ \\
\hline \multirow{4}{*}{$\begin{array}{c}\text { Lereng } \\
\text { Kaki } \\
\text { Gunungapi }\end{array}$} & $\begin{array}{c}\text { Pakem } \\
\text { Binangun }\end{array}$ & 152.3 & 208.4 & 218.3 & 187.5 & 100.2 & 50.1 & 25.0 & 12.5 & 6.3 & 31.1 & 105.8 & 160.0 & 1257.5 & $1,762,993$ & $2,216,963$ \\
\hline & Umbulmartani & 134.9 & 187.3 & 191.1 & 161.9 & 81.9 & 41.0 & 20.5 & 10.2 & 5.1 & 20.6 & 80.3 & 129.2 & 1064.0 & $2,037,388$ & $2,167,817$ \\
\hline & Sardonoharjo & 122.6 & 170.2 & 164.8 & 137.3 & 68.7 & 34.3 & 17.2 & 8.6 & 4.3 & 24.8 & 65.2 & 106.7 & 924.7 & 51,512 & 47,633 \\
\hline & Suko Harjo & 64.9 & 103.4 & 134.4 & 135.4 & 90.0 & 45.0 & 22.5 & 11.2 & 5.6 & 23.5 & 42.6 & 117.1 & 795.6 & $1,157,613$ & 921,043 \\
\hline \multirow{6}{*}{$\begin{array}{c}\text { Dataran } \\
\text { Kaki } \\
\text { Gunungapi }\end{array}$} & Wedomartani & 102.4 & 157.5 & 155.4 & 125.0 & 62.5 & 31.2 & 15.6 & 7.8 & 3.9 & 14.2 & 51.1 & 102.0 & 828.7 & $1,061,666$ & 879,809 \\
\hline & Sardonoharjo & 113.67 & 165.63 & 162.17 & 136.16 & 68.08 & 34.04 & 17.02 & 8.51 & 4.25 & 20.23 & 59.18 & 103.88 & 892.8 & 54,667 & 48,808 \\
\hline & Suko Harjo & 112.2 & 163.2 & 159.0 & 132.2 & 66.1 & 33.0 & 16.5 & 8.3 & 4.1 & 16.9 & 57.7 & 107.3 & 876.4 & $1,025,533$ & 898,773 \\
\hline & Sinduharjo & 106.4 & 160.3 & 156.9 & 128.8 & 64.4 & 32.2 & 16.1 & 8.0 & 4.0 & 18.9 & 54.8 & 101.9 & 852.6 & 405,368 & 345,626 \\
\hline & $\begin{array}{l}\text { Condong } \\
\text { Catur }\end{array}$ & 96.5 & 151.7 & 149.5 & 122.4 & 61.2 & 30.6 & 15.3 & 7.6 & 3.8 & 10.4 & 47.9 & 103.7 & 800.6 & 3,137 & 2,511 \\
\hline & Maguwoharjo & 102.8 & 154.7 & 154.3 & 124.7 & 62.3 & 31.2 & 15.6 & 7.8 & 3.9 & 10.2 & 47.7 & 115.1 & 830.3 & 223,475 & 185,553 \\
\hline \multirow{3}{*}{$\begin{array}{l}\text { Teras } \\
\text { Sungai }\end{array}$} & Wedomartani & 102.3 & 208.6 & 234.3 & 202.8 & 125.0 & 62.5 & 31.3 & 15.6 & 7.8 & 17.1 & 46.0 & 121.7 & 1175.2 & 289,332 & 340,022 \\
\hline & Sinduharjo & 106.4 & 159.5 & 156.5 & 125.4 & 62.7 & 31.4 & 15.7 & 7.8 & 3.9 & 20.2 & 55.5 & 102.4 & 847.4 & 33,141 & 28,085 \\
\hline & Maguwoharjo & 100.1 & 156.5 & 163.0 & 128.8 & 64.4 & 32.2 & 16.1 & 8.1 & 4.0 & 10.1 & 47.4 & 99.1 & 829.8 & 32,904 & 27,302 \\
\hline
\end{tabular}

\section{b. Embung Tambakboyo}

Embung Tambakboyo merupakan suatu bentuk konservasi terhadap air (Gambar 4.1). Bangunan ini menempati tiga desa yaitu, Condongcatur, Maguwoharjo, dan Wedomartani. Embung ini selesai dibangun pada tahun 2009. Luas Embung Tambakboyo adalah 7,8 ha dengan volume tampungan $400.000 \mathrm{~m} 3$ (pustaka.pu.go.id, 2016). Hasil penelitian Alexander dan Harahap (2009) menunjukkan bahwa volume air yang dapat efektif digunakan di embung ini senilai 134.627,41 m3/hari.

\section{c. Mataair}

Mata air di DAS Sembung terdapat pada tekuk lereng antara lereng kaki dengan dataran kaki (Gambar 4.2). Selain itu mata air ini juga muncul pada area hulu di ujung batas DAS. Mata air ini muncul akibat kontak antara lereng dengan kemiringan berbeda (lereng kaki dengan dataran 
kaki). Jumlah mata air yang ada berjumlah tiga pada desa berbeda (Tabel 4.7). Mata air ini tergolong ke dalam kelas V menurut Todd (1954) karena memiliki debit 1-10 1/detik. Aliran mata air tersebut digunakan sebagai air irigasi persawahan bersama irigasi yang bersumber dari Sungai Sembung maupun Kalikuning.

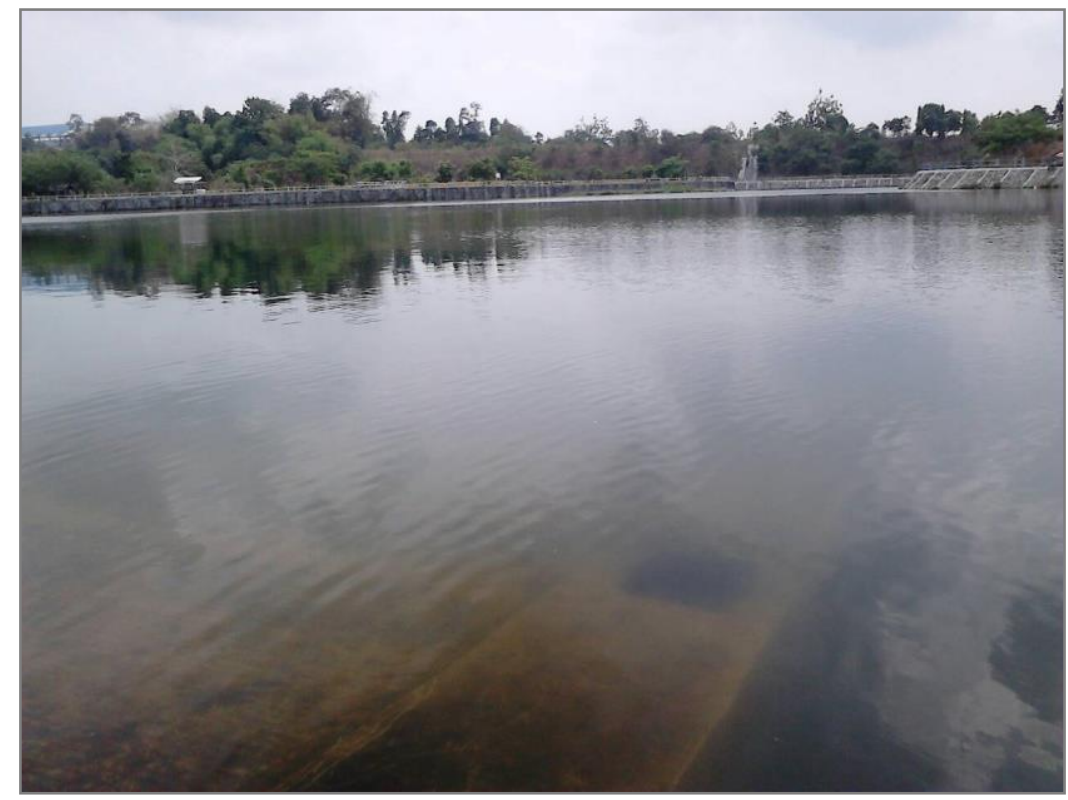

Gambar 4.1. Embung Tambakboyo
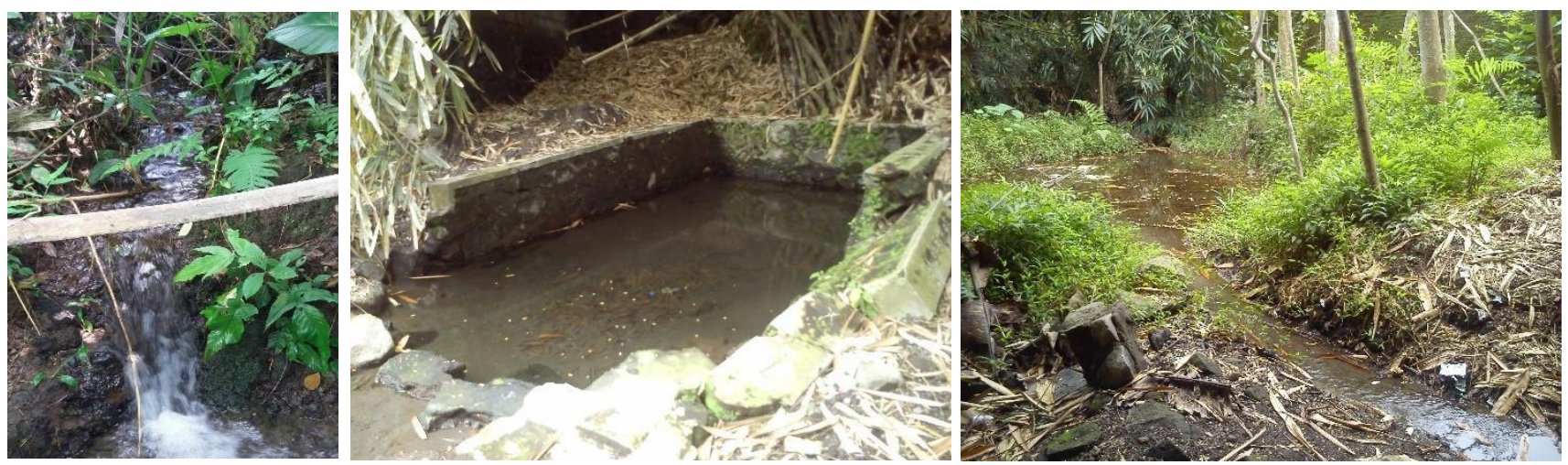

Gambar 4.2. Mataair di Desa Pakembinangan (kiri), Umbulmartani (tengah), dan Sukoharjo (kanan)

Tabel 4.7 Debit mata air di DAS Sembung

\begin{tabular}{|c|c|c|c|c|}
\hline BL & Desa & $\mathbf{X}$ & $\mathbf{Y}$ & Debit (m3/s) \\
\hline \multirow{2}{*}{ Lereng Kaki } & Pakembinangun & 436662 & 9154500 & 0.006 \\
\cline { 2 - 5 } & Umbulmartani & 436925 & 9151142 & 0.0003 \\
\hline Dataran Kaki & Sukoharjo & 435647 & 9148663 & 0.004 \\
\hline
\end{tabular}

\subsection{Ketersediaan Airtanah}


Sistem akuifer DAS Sembung termasuk ke dalam ssistem akuifer lereng Merapi bagian Selatan. Hal ini ditunjukkan dengan formasi batuan Endapan Merapi (Qmi). Formasi ini terdiri dari Tuff, Abu, Breksi, Agglomerat, dan Leleran Lava Tak Terpisahkan. Hal ini menyebabkan kondisi akuifer di DAS Sembung termasuk ke dalam jenis akuifer isotropis. Akuifer isotropis merupakan akuifer yang arah alirannya memiliki kesempatan yang sama untuk menuju ke segala arah. Kondisi geologis dan geomorfologis menyebabkan sistem akuifer porus yang mengalir dari hulu ke hilir (dinamis). Pengukuran ketersediaan airtanah di DAS Sembung menggunakan metode Darcy. Berdasarkan material yang ada di DAS Sembung menyebabkan konduktivitas hidrolik di DAS Sembung mencapai $14,76 \mathrm{~m} / \mathrm{hari}$. Hal ini akan berpengaruh terhadap potensi airtanah yang ada di DAS Sembung.

Hasil perhitungan menunjukkan kondisi ketersediaan airtanah di daerah lereng kaki ditunjukkan dengan adanya mataair dan airtanah (Tabel 4.8). Kondisi airtanah tertinggi di Dataran Kaki Volkan yaitu di Desa Sukoharjo. Desa Sukoharjo memiliki volume airtanah sebesar 12,8 $\mathrm{m}^{3}$ di lereng kaki dan. Volume mataair yang ada dikeluarkan sebesar di Desa Sukoharjo 0,126 $\mathrm{m}^{3}$ di lereng kaki.. Mataair-mataair tersebut ditemukan di Desa Pakem Binangun, Umbulmartani dengan volume $0,189 \mathrm{~m}^{3}$ dan $0,009 \mathrm{~m}^{3}$. Kondisi airtanah selain di Desa Sukoharjo seperti Desa Pakem Binangun, Umbulmartani dan Sardonoharo memiliki volume secara berturut-turut 8,2 $\mathrm{m}^{3}, 6,6 \mathrm{~m}^{3}$, dan $0,7 \mathrm{~m}^{3}$. Kondisi airtanah dengan volume terkecil di Lereng kaki yaitu $0,7 \mathrm{~m}^{3}$ berada di Desa Sardonoharjo.

Tabel 4.8 Ketersediaan Airtanah dan Mata Air di DAS Sembung

\begin{tabular}{|c|c|c|c|}
\hline DESA & BL & Airtanah(m3) & $\begin{array}{c}\text { Mataair } \\
(\mathbf{m 3})\end{array}$ \\
\hline \multirow{4}{*}{$\begin{array}{c}\text { Lereng Kaki } \\
\text { Gunungapi }\end{array}$} & $\begin{array}{c}\text { Pakem } \\
\text { Binangun }\end{array}$ & 8,2 & 0,189 \\
\cline { 2 - 4 } & Umbulmartani & 6,6 & 0,009 \\
\cline { 2 - 4 } & Sardonoharjo & 0,7 & 0 \\
\cline { 2 - 4 } & Suko Harjo & 12,8 & 0,126 \\
\hline \multirow{4}{*}{$\begin{array}{c}\text { Dataran Kaki } \\
\text { Gunungapi }\end{array}$} & Wedomartani & 6,1 & 0 \\
\cline { 2 - 4 } & Suko Harjo & 13,9 & 0,126 \\
\cline { 2 - 4 } & Sinduharjo & 5,5 & 0 \\
\cline { 2 - 4 } & $\begin{array}{c}\text { Condong } \\
\text { Catur }\end{array}$ & 0,2 & 0 \\
\cline { 2 - 4 } & Maguwoharjo & 1,8 & 0 \\
\hline
\end{tabular}


Ketersediaan airtanah di Dataran Kaki Volkan terbesar ditunjukkan di Desa Sukoharjo yaitu sebesar 13,9 $\mathrm{m}^{3}$. Ketersediaan airtanah terkecil di Condongcatur yaitu $0,2 \mathrm{~m}^{3}$. Ketersediaan airtanah Wedomartani, Sinduharjo dan Maguwoharjo sebesar 6,1 $\mathrm{m}^{3}, 5,5 \mathrm{~m}^{3}$ dan 1,8 $\mathrm{m}^{3}$. Dijumpai pula mataair di Dataran Kaki Volkan yaitu di Desa Sukoharjo dengan volume 0,126 $\mathrm{m}^{3}$. Hal ini menunjukkan bahwa Desa Sukoharo memiliki potensi airtanah terbesar di DAS Sembung. Desa Sukoharjo merupakan salah satu tekuk lereng Merapi yang membatasi bentuklahan lereng kaki dan dataran kaki di DAS Sembung. Hal ini ditunjukkan dengan adanya kemunculan mataair di Desa Sukoharjo. Ketersediaan airtanah terkecil di DAS Sembung terdapat di Desa Condongcatur dan ketersediaan terbesar di Desa Sukoharjo.

\subsection{Kebutuhan Air}

\section{a. Kebutuhan Air Domestik}

Satuan lahan lereng kaki memiliki jumlah penduduk sebesar 12.638 jiwa. Jumlah penduduk sebesar 12.638 jiwa tersebut tersebar ke dalam 4 desa yang berada di dalam satuan lereng kaki DAS Sembung, yaitu : Pakembinangun sebesar 3.596 jiwa, Umbulmartani sebesar 4156 jiwa, Sardonoharjo sebesar 433 jiwa, dan Sukoharjo sebesar 4.453 jiwa. Jika diklasifikasikan berdasarkan Tabel Standar Kebutuhan Air Domestik berdasarkan Jenis Kota dan Jumlah Penduduk (Pedoman Konstruksi dan Bangunan, Dep. PU dalam Direktorat Pengairan dan Irigasi Bappenas, 2006), tiap desa di lereng kaki DAS Sembung tergolong ke dalam jenis kota kecil dengan baku kebutuhan air domestik masing - masing, yaitu : Pakembinangun sebesar 68,46 liter/orang/hari, Umbulmartani sebesar 69,78 liter/orang/hari, Sardonoharjo sebesar 17,22 liter/orang/hari, dan Sukoharjo sebesar 70,48 liter/orang/hari.

Jika baku kebutuhan air domestik dikalikan dengan jumlah penduduk, maka dihasilkan nilai kebutuhan air domestik tiap desa di lereng kaki DAS Sembung masing - masing, yaitu : Pakembinangun sebesar 89859,41 m3/tahun, Umbulmartani sebesar 105842,84 m3/tahun, Sardonoharjo sebesar 2722,39 m3/tahun, dan Sukoharjo sebesar 114552,03 m3/tahun (Tabel 4.9). Nilai kebutuhan air domestik tiap desa di lereng kaki DAS Sembung berbeda - beda, hal tersebut dipengaruhi oleh jumlah penduduk yang tinggal di tiap desa. Semakin besar jumlah penduduk yang ada di dalam suatu desa, maka semakin tinggi nilai kebutuhan air domestik yang dihasilkan. 
Tabel 4.9 Tabel Kebutuhan Air Domestik di Lereng Kaki

\begin{tabular}{|c|c|c|c|c|c|}
\hline KECAMATAN & DESA & Luas (m2) & $\begin{array}{c}\text { Jumlah } \\
\text { Penduduk (jiwa) }\end{array}$ & $\begin{array}{c}\text { Baku Kebutuhan } \\
\text { Air Domestik } \\
\text { (liter/orang/hari) }\end{array}$ & $\begin{array}{c}\text { Kebutuhan } \\
\text { Air Domestik } \\
\text { (m3/tahun) }\end{array}$ \\
\hline Pakem & Pakembinangun & 1.762 .993 & 3.596 & 68,46 & $89.859,40$ \\
\hline Ngemplak & Umbulmartani & 2.037 .388 & 4.156 & 69,77 & $105.842,84$ \\
\hline Ngaglik & Sardonoharjo & 212.358 & 433 & 17,21 & $2.722,39$ \\
\hline Ngaglik & Suko Harjo & 2.183 .146 & 4.453 & 70,47 & $114.552,03$ \\
\hline
\end{tabular}

Satuan lahan dataran kaki memiliki jumlah penduduk sebesar 4.373 jiwa. Jumlah penduduk sebesar 4.374 jiwa tersebut tersebar ke dalam 5 desa yang berada di dalam satuan dataran kaki DAS Sembung, yaitu : Wedomartani sebesar 1.396 jiwa, Sukoharjo sebesar 2.256 jiwa, Sinduharjo sebesar 453 jiwa, Condongcatur sebesar 3 jiwa, dan Maguwoharjo sebesar 265 jiwa. Jika diklasifikasikan berdasarkan Tabel Standar Kebutuhan Air Domestik berdasarkan Jenis Kota dan Jumlah Penduduk (Pedoman Konstruksi dan Bangunan, Dep. PU dalam Direktorat Pengairan dan Irigasi Bappenas, 2006), tiap desa di dataran kaki DAS Sembung tergolong ke dalam jenis kota kecil dengan baku kebutuhan air domestik masing - masing, yaitu : Wedomartani sebesar 63.28 liter/orang/hari, Sukoharjo sebesar 47,60 liter/orang/hari, Sinduharjo sebesar 17,55 liter/orang/hari, Condongcatur sebesar 10,05 liter/orang/hari, dan Maguwoharjo sebesar 14,42 liter/orang/hari.

Jika baku kebutuhan air domestik dikalikan dengan jumlah penduduk, maka dihasilkan nilai kebutuhan air domestik tiap desa di dataran kaki DAS Sembung masing - masing, yaitu : Wedomartani sebesar 32.245.00 m3/tahun, Sukoharjo sebesar 39.189,30 m3/tahun, Sinduharjo sebesar 2.902,73 m3/tahun, Condongcatur sebesar 11,89 m3/tahun, dan Maguwoharjo sebesar 1.393,84 m3/tahun (Tabel 4.10). Nilai kebutuhan air domestik tiap desa di lereng kaki DAS Sembung berbeda - beda, hal tersebut dipengaruhi oleh jumlah penduduk yang tinggal di tiap desa. Semakin besar jumlah penduduk yang ada di dalam suatu desa, maka semakin tinggi nilai kebutuhan air domestik yang dihasilkan.

\section{b. Kebutuhan Air Irigasi}

Kebutuhan air untuk irigasi pertanian pada Tabel 4.11 dipengaruhi oleh beberapa faktor, seperti luas sawah (A), baku kebutuhan air sawah (qs), dan frekuensi tanam (ft). Faktor yang paling mempengaruhi perbedaan hasil perhitungan kebutuhan air irigasi pada daerah satu dengan yang lain adalah faktor luas lahan pertanian. Kebutuhan air untuk kepentingan irigasi ini sangat diperlukan karena lahan sawah pada khususnya membutuhkan air dalam jumlah yang banyak sejak 
dari masa penyiapan lahan sampai masa pertumbuhan tanaman padi. DAS Sembung memiliki 3 bentuklahan di mana pada lereng kaki dan dataran kaki memiliki lahan sawah sedangkan pada bentuklahan teras kaki tidak memiliki lahan sawah.

Tabel 4.10. Tabel Kebutuhan Air Domestik di Dataran Kaki

\begin{tabular}{|c|c|c|c|c|c|}
\hline KECAMATAN & DESA & Luas (m2) & $\begin{array}{c}\text { Jumlah Penduduk } \\
\text { (jiwa) }\end{array}$ & $\begin{array}{c}\text { Baku } \\
\text { Kebutuhan Air } \\
\text { Domestik } \\
\text { (liter/orang/hari) }\end{array}$ & $\begin{array}{c}\text { Kebutuhan } \\
\text { Air Domestik } \\
\text { (m3/tahun) }\end{array}$ \\
\hline Ngemplak & Wedomartani & 1.350 .999 & 1396 & 63.28 & $32.244,99$ \\
\hline Ngaglik & Sukoharjo & 2.183 .146 & 2256 & 47.59 & $39.189,29$ \\
\hline Ngaglik & Sinduharjo & 438.509 & 453 & 17.55 & $2.902,72$ \\
\hline Depok & Condongcatur & 3.137 & 3 & 10.05 & 11,89 \\
\hline Depok & Maguwoharjo & 256.379 & 265 & 14.4 & $1.393,83$ \\
\hline
\end{tabular}

Bentuklahan lereng kaki gunungapi memiliki kebutuhan air untuk irigasi yang paling besar dibandingkan kebutuhan air pada dataran kaki. Kondisi ini disebabkan karena luas sawah yang ada di lereng kaki lebih besar daripada luas sawah di dataran kaki yakni sebesar 321,97 ha. Persentase luas wilayah lereng kaki juga lebih besar yang masuk dalam DAS Sembung. Kebutuhan air untuk irigasi pertanian pada lereng kaki pada masing-masing desa dapat dilihat pada tabel di atas. Kebutuhan air irigasi yang paling besar dimiliki oleh Desa Pakembinangun sebesar 2.430.012 ( $\mathrm{m}^{3} /$ tahun) dan kebutuhan air yang paling rendah adalah sebesar 1.317 ( $\mathrm{m}^{3} /$ tahun). Lahan sawah yang ada di lereng kaki ini didominasi oleh lahan sawah irigasi. Hal tersebut jelas terlihat pada hasil interpretasi citra dan survey lapangan yang telah dilakukan menunjukkan bahwa penggunaan lahan sebagai sawah dominan pada bentuklahan ini. Selain itu, faktor kemiringan lereng yang tergolong landai pada lereng kaki menyebabkan supply air untuk irigasi sangat diperlukan, karena potensi air tanah yang dapat digunakan lebih rendah jika dibandingkan pada daerah dataran kaki. Aliran permukaan pada bentuklahan ini juga tinggi sehingga mempengaruhi kebutuhan air yang ada.

Bentuklahan dataran kaki gunungapi memiliki kebutuhan air irigasi yang lebih rendah dari lereng kaki. Kebutuhan air yang paling besar di dataran kaki dimiliki oleh Desa Sukoharjo sebesar 1.267.040 ( $\mathrm{m}^{3} /$ tahun) sedangkan kebutuhan air yang paling rendah dimiliki oleh Desa Condongcatur sebesar 0 ( $\mathrm{m}^{3} /$ tahun). Lahan sawah yang ada pada bentuklahan ini lebih sempit dan cakupan wilayah dataran kaki yang masuk dalam DAS Sembung juga lebih sempit dari lereng kaki. Selain itu, pada peta penggunaan lahan DAS Sembung dan hasil survey lapangan 
menunjukkan bahwa pada bentuklahan ini dominan sebagai permukiman. Perbedaan kebutuhan air irigasi pertanian pada setiap bentuklahan yang ada di DAS Sembung menunjukkan bahwa jika harus dibangun bangunan irigasi yang dapat mendukung kehidupan tanaman maka yang diprioritaskan adalah daerah lereng kaki. Hal ini juga didasari hasil wawancara yang telah dilakukan menunjukkan bahwa pada saat musim kemarau sering terjadi defisit air sehingga lahan sawah harus diganti dengan tanaman lain yang memiliki kebutuhan air lebih rendah dari padi.

Tabel 4.11. Kebutuhan Air untuk Irigasi Pertanian di DAS Sembung

\begin{tabular}{|c|c|c|c|c|c|c|}
\hline \multirow{2}{*}{ BL } & Desa & $\begin{array}{c}\text { Luas } \\
\text { Sawah }(\mathbf{m})\end{array}$ & $\begin{array}{c}\text { Luas Sawah } \\
(\mathbf{h a})\end{array}$ & $\mathbf{q s}$ & $\mathbf{f t}$ & Qi \\
\hline \multirow{4}{*}{ Lereng kaki } & Pakembinangun & 1.406 .257 & 140,63 & 1 & 2 & 2.430 .012 \\
\cline { 2 - 7 } & Umbulmartani & 1.378 .080 & 137,81 & 1 & 2 & 2.381 .322 \\
\cline { 2 - 7 } & Sukoharjo & 434.367 & 43,44 & 1 & 2 & 750.586 \\
\cline { 2 - 7 } & Sardohoharjo & 762 & 0,08 & 1 & 2 & 1.317 \\
\hline \multirow{4}{*}{ Dataran kaki } & Wedomartani & 373.305 & 37,33 & 1 & 2 & $645 . .071$ \\
\cline { 2 - 7 } & Sukoharjo & 733.241 & 73,32 & 1 & 2 & 1267.040 \\
\cline { 2 - 7 } & Sinduharjo & 294.981 & 29,50 & 1 & 2 & 509.727 \\
\cline { 2 - 7 } & Condongcatur & 0 & 0,00 & 1 & 2 & 0 \\
\cline { 2 - 7 } & Maguwoharjo & 11.470 & 1,15 & 1 & 2 & 19.820 \\
\hline
\end{tabular}

\section{c. Kebutuhan Air Industri}

Perhitungan kebutuhan air industri dilakukan berdasarkan bentuk lahan di Sub DAS Sembung meliputi lereng kaki dan dataran kaki. Jumlah total tenaga kerja didapat dari data Kecamatan dalam angka tahun 2015. Jumlah hari kerja industri yaitu 288 hari dengan asumsi 6 hari kerja dan dikurangi dengan hari libur nasional dan cuti. Hasil perhitungan kebutuhan air industri dapat dilihat pada Tabel 4.12.

Tabel 4.12. Kebutuhan Air industri di Sub DAS Sembung

\begin{tabular}{|c|c|c|c|}
\hline Bentuklahan & $\begin{array}{c}\text { Jumlah tenaga } \\
\text { kerja }\end{array}$ & $\begin{array}{c}\text { Jumlah hari } \\
\text { kerja }\end{array}$ & Qid \\
\hline lereng kaki & 142 & 288 & 20.448 \\
\hline dataran kaki & 721 & 288 & 103.824 \\
\hline
\end{tabular}

Berdasarkan Tabel 4.12, daerah dataran kaki memiliki nilai kebutuhan air industri lebih besar dibandingkan lereng kaki yaitu sebesar $20.448 \mathrm{~m}^{3} /$ tahun. Kemudian daerah lereng kaki tercatat sebesar $103.824 \mathrm{~m}^{3} /$ tahun. Munculnya perbedaan jumlah kebutuhan air industri pada setiap bentuk lahan ini disebabkan oleh jumlah tenaga kerja yang bekerja di daerah tersebut. Jumlah 
tenaga kerja di dataran kaki lebih banyak yaitu sebesar 721 karyawan dan di lereng kaki sebesar 142 karyawan.

Perbedaan jumlah karyawan ini terjadi karena penduduk di lereng kaki banyak pula yang bekerja sebagai petani. Selain itu daerah dataran kaki memiliki jumlah tenaga kerja yang lebih besar dibandingkan dengan dengan lereng kaki dikarenakan wilayahnya cenderung lebih strategis, akses yang lebih dekat dengan jalan utama serta jumlah penduduk lebih padat dibandingkan dengan lereng kaki yang daerahnya cenderung landai. Aksesibiltas yang tinggi menjadi penyebab banyaknya industri-industri yang berkembang didaerah tersebut sehingga banyak menyerap tenaga kerja. Adapun industri yang berkembang didaerah-daerah kajian dapat berupa jenis industri kecil dan industri sedang dibidang pengolahan hasil pertanian.

\section{d. Kebutuhan Air Peternakan}

Tabel 4.13 menunjukan bahwa kebutuhan air untuk peternakan di satuan bentuklahan lereng kaki lebih besar di bandingkan di dataran kaki. Besar kebutuhan air satuan bentuklahan lereng kaki sebanyak 14.250 1/kep/hari, sedangkan kebutuhan air satuan bentuklahan dataran sebanyak $3.632 \mathrm{l} / \mathrm{kep} / \mathrm{hari}$. Indikator yang paling berpengaruh terhadap perbedaan jumlah kebutuhan di 2 satuan bentuklahan tersebut adalah jumlah ternak di masing-masing satuan bentuklahan. Jumlah ternak satuan bentuklahan lereng sebanyak 50.624 ekor termasuk didalamnya kerbau, sapi, dan unggas, sedangkan jumlah ternak satuan bentuklahan dataran sebanyak 8.448 ekor.

Tabel 4.13. Tabel Kebutuhan Air Peternakan

\begin{tabular}{|c|c|c|c|c|c|c|c|c|c|c|c|}
\hline \multirow[b]{2}{*}{ 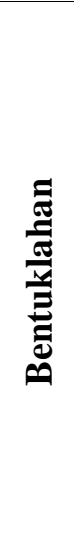 } & \multirow[b]{2}{*}{$\stackrel{\mathscr{W}}{\mathscr{S}^{\circ}}$} & \multicolumn{9}{|c|}{ Jumlah } & \multirow[b]{2}{*}{$\begin{array}{c}\text { QT } \\
\text { (1/kep/hari) }\end{array}$} \\
\hline & & 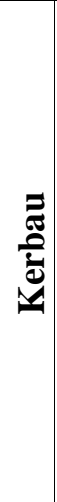 & ב气 & हैं & 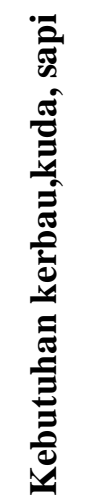 & 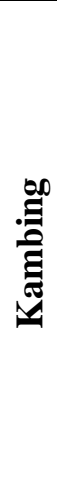 & ڤ્̊ & 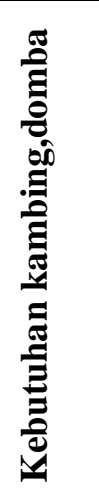 & 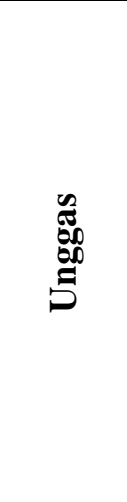 & 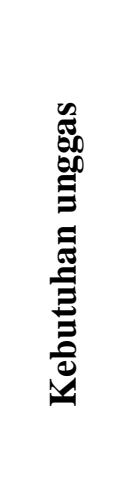 & \\
\hline \multirow{4}{*}{ 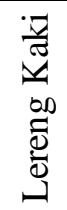 } & Pakembinangun & 0 & 0 & 0 & 0 & 0 & 0 & 0 & 0 & 0 & \multirow{4}{*}{14.250} \\
\hline & Umbulmartani & 1 & 0 & 219 & 8800 & 0 & 0 & 0 & 50.404 & 30.242 & \\
\hline & Sardonoharjo & 0 & 0 & 0 & 0 & 0 & 0 & 0 & 0 & 0 & \\
\hline & Sukoharjo & 0 & 0 & 0 & 0 & 0 & 0 & 0 & 0 & 0 & \\
\hline
\end{tabular}




\begin{tabular}{|c|c|c|c|c|c|c|c|c|c|c|c|}
\hline \multirow[b]{2}{*}{ 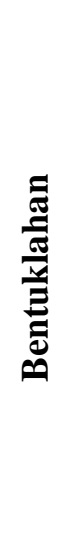 } & \multirow[b]{2}{*}{$\begin{array}{l}\mathscr{W} \\
\stackrel{\mathscr{H}}{0} \\
\end{array}$} & \multicolumn{9}{|c|}{ Jumlah } & \multirow[b]{2}{*}{$\begin{array}{c}\text { QT } \\
\text { (1/kep/hari) }\end{array}$} \\
\hline & & 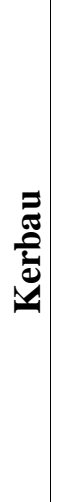 & 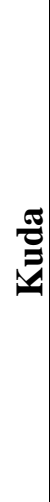 & 宗 & 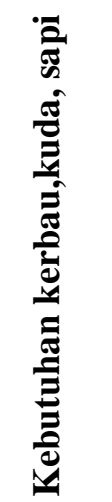 & 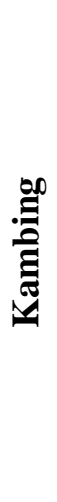 & है & 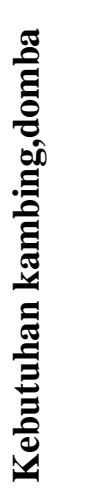 & 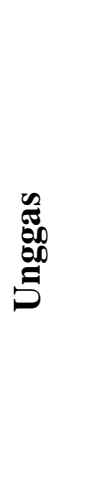 & 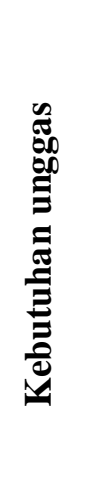 & \\
\hline \multirow{5}{*}{ 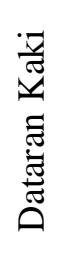 } & Sukoharjo & 0 & 0 & 0 & 0 & 0 & 0 & 0 & 0 & 4.651 & \multirow{5}{*}{3.632} \\
\hline & Wedomartani & 0 & 0 & 117 & 4.680 & 0 & 0 & 0 & 0 & 0 & \\
\hline & Sinduharjo & 0 & 0 & 0 & 0 & 0 & 0 & 0 & 0 & 0 & \\
\hline & Condongcatur & 0 & 0 & 0 & 0 & 0 & 0 & 0 & 0 & 2 & \\
\hline & Maguwoharjo & 0 & 0 & 5 & 200 & 17 & 0 & 85 & 0 & 333 & \\
\hline
\end{tabular}

Indikator lain yang berpengaruh dalam besarnya jumlah kebutuhan ternak adalah jenis ternak itu sendiri. Masing-masing ternak memiliki kebutuhan baku tersendiri dalam sehari. Ternak sejenis kerbau, kuda dan sapi memiliki kebutuhan baku air sehari sebesar 40 liter, sedangkan domba, kambing hanya 5 liter dalam sehari, selain itu unggas hanya memiliki kebutuhan baku sebesar 0,6 liter sehari. Indikasinya, kebutuhan air untuk ternak jenis kuda, sapi dan kerbau lebih besar dari ternak domba, kambing maupung unggas.

\section{e. Kebutuhan Air Perikanan}

Perhitungan kebutuhan air perikanan membutuhkan data luasan kolam dan data kebutuhan air untuk pembilasan. Air untuk pembilasan diestimasikan sebesar 7mm/hari/ha karena ketika air kolam diganti hanya sepertiga tinggi genangan kolam. Berdasarkan hasil perhitungan kebutuhan air pada kedua bentuklahan yaitu lereng kaki dan dataran kaki didapatkan hasil bahwa pada lereng kaki kebutuhan air perikanannya lebih besar dibandingkan dengan dataran kaki. Kebutuhan air pada kaki lereng yaitu didapatkan hasil sebesar 517.484.620,07 $\mathrm{m}^{3} /$ tahun sedangkan pada dataran kaki sebesar 54.773,80 $\mathrm{m}^{3} /$ tahun (Tabel 4.14). Hal ini disebabkan karena pada bentuklahan lereng kaki luasan kolamnya lebih besar dibandingkan pada dataran kaki. Luasan kolam paling luas yaitu terdapat pada desa Pakembinangun yang terletak pada kaki lereng. Pada bentuklahan dataran kaki total luasan kolamnya sangat kecil karena kegiatan perikanan pada dataran kaki sangat sedikit ditemui 
Tabel 4.14. Tabel Kebutuhan Air Perikanan

\begin{tabular}{|c|c|c|c|c|}
\hline \multirow{5}{*}{ LERENG KAKI } & DESA & $\begin{array}{c}\text { Luas Desa } \\
\text { (ha) }\end{array}$ & Afp & $\begin{array}{c}\text { Qfp } \\
\text { (m3/tahun) }\end{array}$ \\
\hline & Pakembinangun & 1762993 & 20250,93 & 517411289,77 \\
\hline & Umbulmartani & 2037388 & 2,34 & 59876,44 \\
\hline & Sardonoharjo & 212358 & 0,08 & 1962,92 \\
\hline & Sukoharjo & 2183146 & 0,45 & 11490,93 \\
\hline \multicolumn{4}{|c|}{ Total } & $517.484 .620,07$ \\
\hline \multirow{7}{*}{$\begin{array}{c}\text { DATARAN } \\
\text { KAKI }\end{array}$} & DESA & $\begin{array}{c}\text { Luas Desa } \\
\text { (ha) }\end{array}$ & Afp & $\begin{array}{c}\text { Qfp } \\
\text { (m3/tahun) }\end{array}$ \\
\hline & Wedomartani & 1350999 & 1,43 & 36544,59 \\
\hline & Sukoharjo & 2183146 & 0,45 & 11490,93 \\
\hline & Sinduharjo & 438509 & 0,15 & 3941,15 \\
\hline & Condongcatur & 3137 & 0,02 & 479,22 \\
\hline & Maguwoharjo & 256379 & 0,09 & 2317,91 \\
\hline & \multicolumn{3}{|c|}{ Total } & $54.773,80$ \\
\hline
\end{tabular}

\subsection{Kekritisan DAS}

Kekritisan DAS merupakan perbandingan antara air yang tersedia disetiap desa dengan kebutuhan air total yang ada. Tabel 4.54 menunjukkan bahwa seluruh desa di DAS Sembung tergolong tidak kritis $(<50 \%)$. Hal ini menunjukkan bahwa ketersediaan air yang ada mampu mencukupi kebutuhan air di seluruh desa di DAS Sembung. Ketersediaan air di DAS Sembung berasal dari limpasan air permukaan, air tanah, mata air, dan embung.

Bentuklahan lereng kaki memiliki ketersediaa air paling besar pada air tanah. Tabel 4.15 menunjukkan bahwa Desa Pakembinangun memiliki debit airtanah 8,2 juta m3/tahun Sukoharjo 12,8 juta m3/tahun, Umbulmartani 6,6 juta m3/tahun, dan Sardonoharjo 0,7 juta m3/tahun. Sementara itu, total kebutuhan air setiap desa di satuan lahan ini paling tinggi berada pada Desa Pekembinangun dan dan Umbulmartani dengan total sekitar 2,57 juta m3/tahun di setiap desa. Kebutuhan kedua desa tersebut paling tinggi akibat jumlah air untuk sawah irigasi yang besar. Hal ini sesuai dengan penggunaan lahan di kedua desa dimana luas lahan pertanian mencapai $70 \%$. Kebutuhan air irigasi de kedua desa tersebut selama ini dapat dicukupi dengan sumber air permukaan (sungai dan irigasi) dan mata air. Penggunaan airtanah di lereng kaki lebih dioptimalkan untuk kebutuhan domestik.

Sumberdaya air di lereng kaki dapat dikatakan melimpah. Curah hujan yang tinggi menjadikan limpasan permukaan yang ada juga besar. Selama ini, limpasan permukaan tersebut lebih banyak dibiarkan mengalir ke sungai kemudian berlalu. Konservasi air perlu dilakukan untuk 
memanfaatkan secara optimal input air yang besar mengingat tingginya penggunaan lahan untuk sawah irigasi. Tampungan air baik berupa embung atau kolam sederhan dapat dibuat guna menyimpan sumberdaya air permukaan yang besar. Hal ini mengingat melalui hasil perhitungan menunjukkan bahwa kebutuhan air irigasi sangat mendekati ketersediaan air permukaan. Dengan adanya tampungan air permukaan diharapkan airtanah tetap tidak digunakan sebagai air irigasi dan dibiarkan sebagai simpanan air.

Tabel 4.15. Kekritisan Air DAS Sembung

\begin{tabular}{|c|c|c|c|c|c|c|c|c|c|c|c|c|c|c|}
\hline \multirow{2}{*}{ DESA } & \multirow{2}{*}{$\mathbf{B L}$} & \multirow{2}{*}{$\begin{array}{c}\text { Air } \\
\text { Permukaan } \\
(\mathbf{m} 3)\end{array}$} & \multirow{2}{*}{$\begin{array}{c}\text { Air } \\
\text { Tanah } \\
(\mathbf{m} 3)\end{array}$} & \multirow{2}{*}{$\begin{array}{c}\text { Embung } \\
(\mathbf{m} 3)\end{array}$} & \multirow{2}{*}{$\begin{array}{c}\text { Mata } \\
\text { Air } \\
(\mathbf{m} 3)\end{array}$} & \multirow{2}{*}{$\begin{array}{l}\text { Total } \\
(\mathrm{m} 3)\end{array}$} & \multicolumn{6}{|c|}{ Kebutuhan (m3) } & \multirow[t]{2}{*}{$\begin{array}{c}\text { Kekritisan } \\
\text { Air }(\%)\end{array}$} & \multirow[t]{2}{*}{$\begin{array}{c}\text { Tingkat } \\
\text { Kekritisan }\end{array}$} \\
\hline & & & & & & & Irigasi & Perikanan & Industri & Peternakan & Domestik & Total & & \\
\hline \multirow{4}{*}{$\begin{array}{c}\text { Lereng } \\
\text { Kaki } \\
\text { Gunungapi }\end{array}$} & $\begin{array}{c}\text { Pakem } \\
\text { Binangun }\end{array}$ & 2.2 & 8.2 & \multirow{4}{*}{0} & 0.189 & 10.6 & 2.43 & 0.05 & 0.003 & 0 & 0.09 & 2.57 & 24.37 & $\begin{array}{l}\text { Tidak } \\
\text { Kritis }\end{array}$ \\
\hline & Umbulmartani & 2.2 & 6.6 & & 0.009 & 8.8 & 2.381 & 0.06 & 0.006 & 0.0143 & 0.106 & 2.57 & 29.29 & $\begin{array}{l}\text { Tidak } \\
\text { Kritis }\end{array}$ \\
\hline & Sardonoharjo & 0.1 & 0.7 & & 0 & 0.8 & 0.001 & 0 & 0.003 & 0 & 0.003 & 0.01 & 1.25 & $\begin{array}{l}\text { Tidak } \\
\text { Kritis }\end{array}$ \\
\hline & Suko Harjo & 0.9 & 12.8 & & 0.126 & 13.7 & 0.751 & 0.01 & 0.008 & 0 & 0.115 & 0.88 & 6.45 & $\begin{array}{l}\text { Tidak } \\
\text { Kritis }\end{array}$ \\
\hline \multirow{5}{*}{$\begin{array}{c}\text { Dataran } \\
\text { Kaki } \\
\text { Gunungapi }\end{array}$} & Wedomartani & 1.2 & 6.1 & \multirow{5}{*}{49.1} & 0 & 56.4 & 0.645 & 0.04 & 0.012 & 0 & 0.032 & 0.73 & 1.29 & $\begin{array}{l}\text { Tidak } \\
\text { Kritis }\end{array}$ \\
\hline & Suko Harjo & 0.9 & 13.9 & & 0.126 & 64 & 1.267 & 0.01 & 0.073 & 0 & 0.039 & 1.39 & 2.17 & $\begin{array}{l}\text { Tidak } \\
\text { Kritis }\end{array}$ \\
\hline & Sinduharjo & 0.4 & 5.5 & & 0 & 55 & 0.51 & 0 & 0.011 & 0 & 0.003 & 0.53 & 0.96 & $\begin{array}{l}\text { Tidak } \\
\text { Kritis }\end{array}$ \\
\hline & $\begin{array}{l}\text { Condong } \\
\text { Catur }\end{array}$ & 0 & 0.2 & & 0 & 49.4 & 0 & 0 & 0 & 0 & 0 & 0 & 0 & $\begin{array}{l}\text { Tidak } \\
\text { Kritis }\end{array}$ \\
\hline & Maguwoharjo & 0.2 & 1.8 & & 0 & 51.1 & 0.02 & 0 & 0.007 & 0.0002 & 0.001 & 0.03 & 0.06 & $\begin{array}{l}\text { Tidak } \\
\text { Kritis }\end{array}$ \\
\hline
\end{tabular}

Kebutuhan air di satuan dataran kaki secara keseluruhan lebih kecil dibandingkan lereng kaki. Hal ini dikarenakan penggunaan air lebih didominasi oleh penggunaan domestik dibandingkan pertanian. Dataran kaki memang perkembangannya mengarah ke kawasan perkotaan. Hal ini dapat dilihat dari penggunaan lahan berupa dominasi permukiman serta terdapat wahana waterboom dan Stadion Maguwoharjo. Kebutuhan air total di dataran kaki paling tinggi berada di Desa Sukoharjo dengan 1,39 juta m3/tahun karena masih intensifnya pertanian irigasi dan paling rendah berada di Desa Maguwoharjo serta Condongcatur karena luas wilayah yang masuk ke DAS Sembung hanya sedikit.

Ketersediaan air di dataran kaki paling besar berada di simpanan air permukaan dalam bentuk Embung Tambakbayan. Adanya embung ini merupakan suatu bentuk konservasi terhadap air. Embung Tambakbayan mampu menyimpan air efektif untuk kebutuhan sebesar 134.627,4 m3/hari atau 49,13 juta m3/tahun. Jumlah air ini sangat mencukupi kebutuhan air di DAS Sembung. Meskipun demikian, kebutuhan air domestik di dataran kaki masih lebih banyak memanfaatkan air tanah dalam keseharian. Kurangnya pengoptimalan air embung ini diakibatkan 
oleh kualitas air yang kurang baik. Hasil praktikum lapangan kualitas air oleh Departeman Geografi Lingkungan tahun 2015 menunjukkan bahwa parameter BOD melebihi baku mutu ketika jam kerja (08.00 - 13.00). Pengolahan IPAL (instalasi pengolahan air limbah) perlu dibuat untuk mengatasi pencemaran air ini.

\section{KESIMPULAN}

Ketersediaan air meteorologis DAS Sembung pada bentuklahan lereng kaki gunungapi sebesar $5.827 .098 \mathrm{~m}^{3} /$ tahun, pada bentuklahan dataran kaki sebesar $2.652 .140 \mathrm{~m}^{3} /$ tahun sedangkan pada teras sungai sebesar $332.024 \mathrm{~m}^{3} /$ tahun. Ketersediaan air meteorologis pada DAS Sembung akan mengalami surplus pada saat musim penghujan dan akan mengalami defisit pada saat musim kemarau.

Kebutuhan air domestik pada DAS Sembung yang paling besar adalah pada bentuklahan lereng kaki sebesar $312.977 \mathrm{~m}^{3} /$ tahun, hal ini dibuktikan dengan jumlah penduduk dan luas desa yang ada lebih besar pada bentuklahan ini. Kebutuhan air irigasi yang paling besar dimiliki oleh bentuklahan lereng kaki yaitu sebesar $5.563 .237 \mathrm{~m}^{3} /$ tahun, kebutuhan air irigasi yang besar ini disebabkan karena luas lahan sawah yang ada lebih luas pada lereng kaki. Kebutuhan air peternakan yang paling besar berada pada bentuklahan lereng kaki yaitu sebesar $14.250 \mathrm{~m}^{3} / \mathrm{tahun}$. Kebutuhan air perikanan yang paling besar berada pada bentuklahan lereng kaki sebesar 125.070 $\mathrm{m}^{3} /$ tahun. Kebutuhan air industri terbesar berada pada bentuklahan dataran kaki yaitu sebesar $103.824 \mathrm{~m}^{3} /$ tahun, hal ini disebabkan karena wilayah ini sudah dekat dengan perkotaan sehingga jumlah industri yang ada lebih besar pada bentuklahan ini.

Tingkat kekritisan air pada bentuklahan lereng kaki, dataran kaki, dan teras sungai pada DAS Sembung tergolong tidak kritis. Hal ini disebabkan karena potensi ketersediaan air yang banyak meliputi airtanah, air permukaan, dan mata air.

\section{DAFTAR PUSTAKA}

Asdak, C. 2007. Hidrologi dan Pengelolaan Daerah Aliran Sungai. Yogyakarta: Gadjah Mada University Press.

Seyhan, Ersin. 1990. Dasar-Dasar Hidrologi (terjemahan Sentot Subagyo). Yogyakarta: Gadjah Mada University Press

Sosrodarsono, S. dan Takeda. 1993. Hidrologi untuk Pengairan. Jakarta: PT Pradnya Paramita. 